\title{
Changes in Andes snow cover from MODIS data, 2000-2016
}

\author{
Freddy A. Saavedra ${ }^{1,2}$, Stephanie K. Kampf ${ }^{3}$, Steven R. Fassnacht ${ }^{3,4,5,6}$, and Jason S. Sibold ${ }^{7}$ \\ ${ }^{1}$ Departamento de Ciencias Geográficas, Facultad de Ciencias Naturales y Exactas, Universidad de Playa Ancha, Leopoldo \\ Carvallo 270, Playa Ancha, Valparaíso, Chile \\ ${ }^{2}$ Centro de Estudios Avanzados, Universidad de Playa Ancha, Traslaviña 450, Viña del Mar, Chile \\ ${ }^{3}$ Department of Ecosystem Science and Sustainability, Colorado State University, Fort Collins, CO 80523-1476, USA \\ ${ }^{4}$ Cooperative Institute for Research in the Atmosphere, Colorado State University, Fort Collins, CO 80523-1375, USA \\ ${ }^{5}$ Natural Resources Ecology Laboratory, Colorado State University, Fort Collins, CO 80523-1499, USA \\ ${ }^{6}$ Geographisches Institut, Georg-August-Universität Göttingen, 37077 Göttingen, Germany \\ ${ }^{7}$ Department of Anthropology, Colorado State University, Fort Collins, CO, USA
}

Correspondence: Freddy A. Saavedra (freddy.saavedra@upla.cl)

Received: 21 April 2017 - Discussion started: 12 May 2017

Revised: 22 January 2018 - Accepted: 30 January 2018 - Published: 23 March 2018

\begin{abstract}
The Andes span a length of $7000 \mathrm{~km}$ and are important for sustaining regional water supplies. Snow variability across this region has not been studied in detail due to sparse and unevenly distributed instrumental climate data. We calculated snow persistence (SP) as the fraction of time with snow cover for each year between 2000 and 2016 from Moderate Resolution Imaging Spectroradiometer (MODIS) satellite sensors ( $500 \mathrm{~m}, 8$-day maximum snow cover extent). This analysis is conducted between 8 and $36^{\circ} \mathrm{S}$ due to high frequency of cloud (>30\% of the time) south and north of this range. We ran Mann-Kendall and Theil-Sens analyses to identify areas with significant changes in SP and snowline (the line at lower elevation where $\mathrm{SP}=20 \%$ ). We evaluated how these trends relate to temperature and precipitation from Modern-Era Retrospective Analysis for Research and Applications-2 (MERRA2) and University of Delaware datasets and climate indices as El Niño-Southern Oscillation (ENSO), Southern Annular Mode (SAM), and Pacific Decadal Oscillation (PDO). Areas north of $29^{\circ} \mathrm{S}$ have limited snow cover, and few trends in snow persistence were detected. A large area $\left(34370 \mathrm{~km}^{2}\right)$ with persistent snow cover between 29 and $36^{\circ} \mathrm{S}$ experienced a significant loss of snow cover $\left(2-5\right.$ fewer days of snow year $\left.{ }^{-1}\right)$. Snow loss was more pronounced (62\% of the area with significant trends) on the east side of the Andes. We also found a significant increase in the elevation of the snowline at 10-30 m year $^{-1}$ south of 29$30^{\circ} \mathrm{S}$. Decreasing SP correlates with decreasing precipitation
\end{abstract}

and increasing temperature, and the magnitudes of these correlations vary with latitude and elevation. ENSO climate indices better predicted SP conditions north of $31^{\circ} \mathrm{S}$, whereas the SAM better predicted SP south of $31^{\circ} \mathrm{S}$.

\section{Introduction}

The influence of a changing climate on snow cover has been studied around the world (Barnett et al., 2005; Dahe et al., 2006; Masiokas et al., 2006; Adam et al., 2009; Brown and Mote, 2009). In snow-dominated basins, snowpack often provides the largest reservoir of water (Masiokas et al., 2006; Adam et al., 2009), which influences stream discharge, affecting erosion, sediment transport, hydropower production, and potential water storage (Hall et al., 2012; Stewart, 2009; Arsenault et al., 2014). Peru, Bolivia, Chile, and Argentina all depend on snow and/or glacier melt for water supply due to short rainy seasons (Bradley et al., 2006; Peduzzi et al., 2010; Masiokas et al., 2010; Rabatel et al., 2013). These basins are sensitive to climate changes that modify either temperature or precipitation. In general, increasing temperatures cause decreases in snow cover by increasing the elevation of the $0{ }^{\circ} \mathrm{C}$ isotherm in mountain regions and/or decreasing the fraction of precipitation falling as snow (Barnett et al., 2005; Brown and Mote, 2009). The magnitude of this effect decreases with increasing elevation (López-Moreno et 
al., 2009). However, snow cover changes can be difficult to predict in areas where temperature increases are accompanied by changes in precipitation (Dahe et al., 2006; Adam et al., 2009). Moreover, decreases in the duration of snowpack cause negative feedbacks due to changes in albedo, which leads to increased absorption of solar radiation, intensification of warming trends, and further reductions in snowpack (Fassnacht et al., 2016).

In the Southern Hemisphere, seasonal snow cover is primarily confined to southern South America. In tropical latitudes $\left(20^{\circ} \mathrm{S}\right)$, the intertropical convergence zone (ITCZ) extends southward during the austral summer (January and February) to produce much of the annual precipitation in the Altiplano region $\left(20^{\circ} \mathrm{S}\right)$ (Barry, 2008). Further south (17 to $31^{\circ} \mathrm{S}$ ), hyper-arid conditions lead to no presence of seasonal snow even at high elevations $(>5000 \mathrm{~m}$ ) (Saavedra et al., 2017) and glaciers above $6700 \mathrm{~m}$ (Hobbs et al., 1999). In extratropical areas $\left(31-35^{\circ} \mathrm{S}\right)$, higher precipitation and lower temperatures lead to extensive austral winter snow cover (Garreaud, 2009; Foster et al., 2009), and strong connections have been identified between precipitation and seasonal snow cover in the central Chilean Andes $\left(33^{\circ} \mathrm{S}\right)$ (Pellicciotti et al., 2007). South America's precipitation patterns are influenced by the El Niño-Southern Oscillation (ENSO), with above average annual precipitation during El Niño events and below average totals La Niña events in central latitudes (30 to $37^{\circ}$ S) (Rutllant and Fuenzalida, 1991; Mernild et al., 2017; Garreaud et al., 2009; Gascoin et al., 2011). The interannual seasonal variability of precipitation in South America has been related to the Southern Annular Mode (SAM) (Vera and Silvestri, 2009; Fogt et al., 2010) and the Pacific Decadal Oscillation (PDO).

Air temperature increases $\left(\sim 0.25^{\circ} \mathrm{C} \mathrm{decade}^{-1}\right)$ have been documented for the central Andes between 1975 and 2001 (Falvey and Garreaud, 2009), and this has led to a rise of the $0^{\circ} \mathrm{C}$ isotherm by $\sim 120 \mathrm{~m}$ in winter and $\sim 200 \mathrm{~m}$ in summer in the same area (Carrasco et al., 2008). However, the impacts of climate change on snow-covered areas throughout South America have not been studied in detail due to sparse and unevenly distributed climate data (Masiokas et al., 2006; Aravena and Luckman, 2009; Cortés et al., 2011). Analyses of 17 surface stations document a non-significant positive linear trend in snow water equivalent (SWE) between 30 and $37^{\circ} \mathrm{S}$ from 1951 to 2007 (Masiokas et al., 2010), with snow patterns strongly linked to year-to-year climatic oscillations (Masiokas et al., 2012). Relatively uncertain or biased input forcing data for the region have limited the ability to conduct snow analyses (Cortés and Margulis, 2017), leaving open questions about patterns of snow accumulation and controls on its interannual variability throughout the Andes (Cortes et al., 2016).

Recent studies have begun to combine remote sensing information with the ground monitoring network to expand the geographic scope of snow studies in the Andes. Fractional snow-covered area information from satellite sensors has been combined with energy balance modeling to reconstruct SWE in an area from 28 to $37^{\circ} \mathrm{S}$ (Cornwell et al., 2016) and in select basins between 30 and $34^{\circ} \mathrm{S}$ (Cortés et al., 2014; Ayala et al., 2014). Across the Andes as a whole, snow modeling has been conducted to estimate snow patterns from 1979 to 2014 (Mernild et al., 2017), but the sparse in situ networks that limit snow trend studies also cause problems for the data used as model inputs over the Andes (Cortés et al., 2016; Yi et al., 2011). Therefore, while modeling studies provide useful information about likely snow patterns, there is still a need for snow observations throughout the region to evaluate how well the models simulate snow patterns. This study is the first observation-based study of snow spatial and temporal patterns across the Andes region, contributing to the open questions about snow accumulation patterns highlighted by Cortes et al. (2016). We use snow cover information from the Moderate Resolution Imaging Spectroradiometer (MODIS) to (1) quantify changes in snow cover and their spatial patterns associated with latitude and elevation in the Andes and (2) assess how these snow cover changes relate to climate variables.

\section{Materials and methods}

\subsection{Study site}

The Andes cross seven countries (Venezuela, Colombia, Ecuador, Peru, Bolivia, Chile, and Argentina) and a wide range of latitudes $\left(10^{\circ} \mathrm{N}\right.$ to $\left.57^{\circ} \mathrm{S}\right)$ (Fig. 1). They represent the highest mountain system outside of Asia and are the longest $(7000 \mathrm{~km})$ mountain chain in the world (Barry, 2008). The Andes have a strong effect on atmospheric circulation (Llamedo et al., 2016), and local climates in the Andes region vary greatly depending on latitude, elevation, and proximity to the ocean (Garreaud et al., 2009).

According to the Modern-Era Retrospective Analysis for Research and Applications-2 (MERRA2) dataset 20002016, precipitation is higher on the windward side (east in the north, west in the south) of the Andes due to the orographic effect (Garreaud et al., 2009; Quintana, 2012) (Fig. 2a). In the northern area (north of $20^{\circ} \mathrm{S}$ ), precipitation is concentrated in the austral summer (DJFM), with higher precipitation on the east side. Areas between 20 and $30^{\circ} \mathrm{S}$ have hyperarid conditions with limited precipitation all year on the west side and greater precipitation on the east side. In this area, wet episodes tend to occur during the austral summer due to strong upper-level easterly winds that enhance moisture transport from Amazonia (Garreaud et al., 2003). South of $30^{\circ} \mathrm{S}$, precipitation has a well-defined annual pattern with a peak of precipitation in austral winter (JJA) (Quintana, 2012; Valdés-Pineda et al., 2015a). At these latitudes, westerlies from the Pacific bring moist air masses inland, and the west side of the Andes receives more precipitation than the east side (Garreaud et al., 2009; Matsuura and Willmott, 2015). 


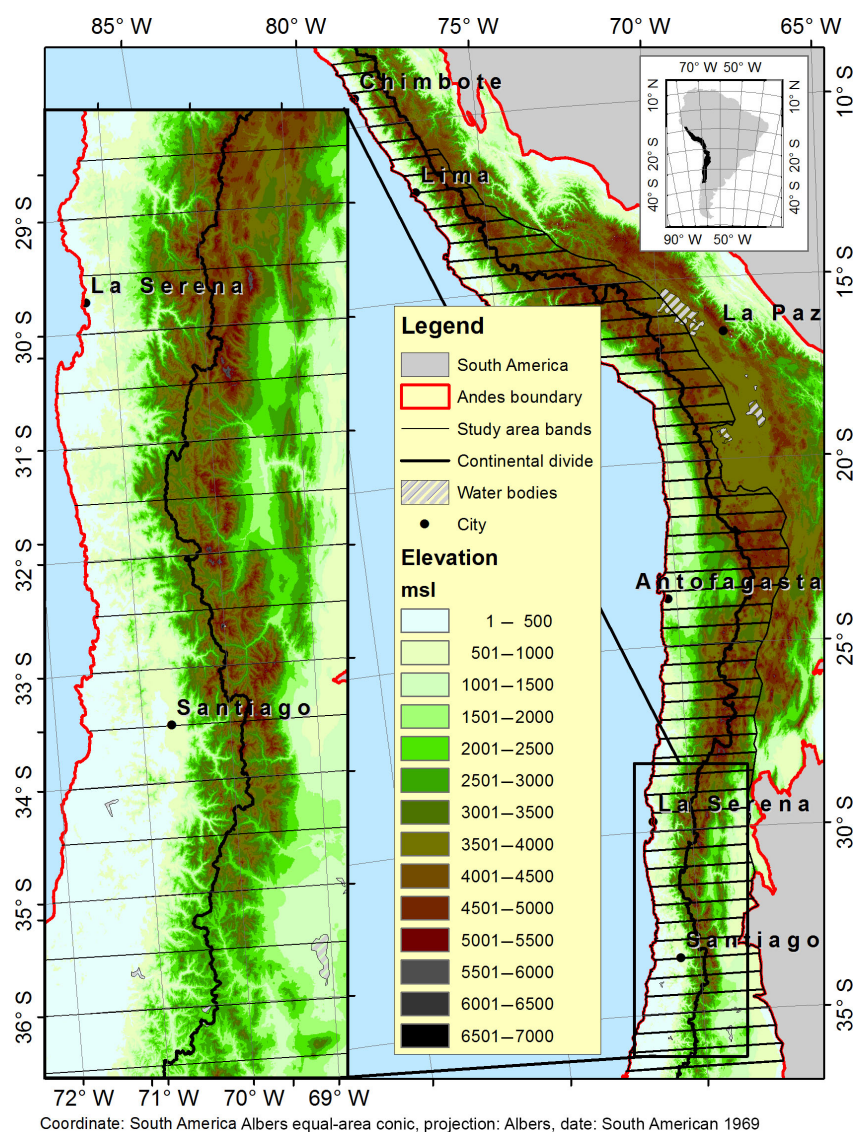

Figure 1. Study area (red line) over digital elevation model of the Central Andes subdivided into $0.5^{\circ}$ latitude bands (black lines). The zoomed-in image highlights the area with more snow.

Throughout the Andes, the lowest mean temperatures are during the austral winter (JJA), and seasonal temperature differences increase with latitude (Fig. 2b). Mean annual temperature decreases from north to south and with increasing elevation. The combined precipitation and temperature patterns affect snow cover duration in the region. Snowfall patterns have been mapped in detail for this region using remote sensing, but high cloud cover ( $>30 \%$ of the time) limited this mapping to the area between 8 and $36^{\circ} \mathrm{S}$ (Saavedra et al., 2017). Saavedra et al. (2017) used the MODIS snow cover product (MOD10A2) to map the monthly average snow-covered area (SCA) from 2000 to 2014 for latitude bands across the Andes (Fig. 2c). The largest snow-covered areas and longest duration snow cover is south of $24^{\circ} \mathrm{S}$. On the west side between 24 and $33^{\circ} \mathrm{S}$, the snow season lasts from around day 110 (20 April) to day 280 (7 October). Between 33 and $35^{\circ} \mathrm{S}$ snow cover can persist all year in highelevation areas $(>5000 \mathrm{~m})$. South of $36^{\circ} \mathrm{S}$, the snow season also starts around day 110 but lasts longer into the austral spring until around day 320 (16 November). The latitudinal variability of snow cover can be summarized using snow persistence (SP), which is the fraction of a year with snow cover.
North of $25^{\circ} \mathrm{S}$, average SP is lower than $10 \%$, and the snowline (defined $\mathrm{SP}=20 \%$ ) is over $5000 \mathrm{~m}$ (Fig. 2d) (Saavedra et al., 2017). The snowline decreases in elevation with increases in latitude south of $25^{\circ} \mathrm{S}$ with a consistently lower snowline on the west side than on the east side of the range (Vuille and Ammann, 1997; Williams and Ferringo, 1998; Barry and Seimon, 2000; Saavedra et al., 2017).

\subsection{Data}

We used the MODIS 8-day $500 \mathrm{~m}$ Collection 5 Level 3 binary snow cover products (Riggs et al., 2006). MODIS is a passive 36-band spectrometer on board two satellites, Terra and Aqua (Hall et al., 2002). One of the spectral bands used to calculate the snow products for the Aqua satellite has malfunctioned, so our research is based on Terra products. Due to the frequent presence of clouds in the daily MODIS snow cover products, we used the 8-day maximum product (MOD10A2), which represents the maximum snow cover and minimum cloud during each 8-day interval (Riggs et al., 2006). The study area is covered by seven MODIS images (tiles), which we downloaded for the time period from 2000 to 2016 (MOD10A2) (http://reverb.echo.nasa.gov), giving a total of 5833 tiles of MOD10A2 (Hall et al., 2006).

We retrieved monthly precipitation $(P)$ and mean temperature $(T)$ from the MERRA2 dataset for 1980-2016 at $0.625^{\circ} \times 0.5^{\circ}$ longitude by latitude grid resolution (https: //gmao.gsfc.nasa.gov/reanalysis/MERRA-2/data_access/).

The MERRA2 model has shown good performance in numerical weather prediction, climate reanalysis, and global mesoscale climate models (Molod et al., 2015). We extended the analysis of $P$ and $T$ back to 1960 by combining MERRA2 data for 1980 2016 with the University of Delaware dataset version 4.01 (UDelv4), which has a grid resolution of $0.5^{\circ}$ for the 1960-1979 period (Legates and Willmott, 1990) (https://gmao.gsfc.nasa.gov/reanalysis/MERRA-2/data_access/). For the study area, UDelv4 compiled data from instrumental ground stations (35 stations across the study area) at a monthly time step from several sources including Global Historical Climatology Network Monthly, Daily Global Historical Climatology Network, Global Synoptic Climatology Network, and Global Surface Summary of Day. The monthly averages of station data were interpolated to a $0.5^{\circ} \times 0.5^{\circ}$ latitude by longitude grid using the spherical version of Shepard's distance-weighting method. In addition, station-by-station cross validation was employed to evaluate the spatial interpolation errors (Willmott and Matsuura, 2005).

An important source of interannual climate variability in the region is ENSO (Masiokas et al., 2012; Cortés et al., 2016). We retrieved 3-month running mean values of four indices (MEI, SOI, ONI, and TNI) and four sea surface temperature (SST) regions $(1+2,3,3.4$, and 4) that describe ENSO behavior. These values are available at a 


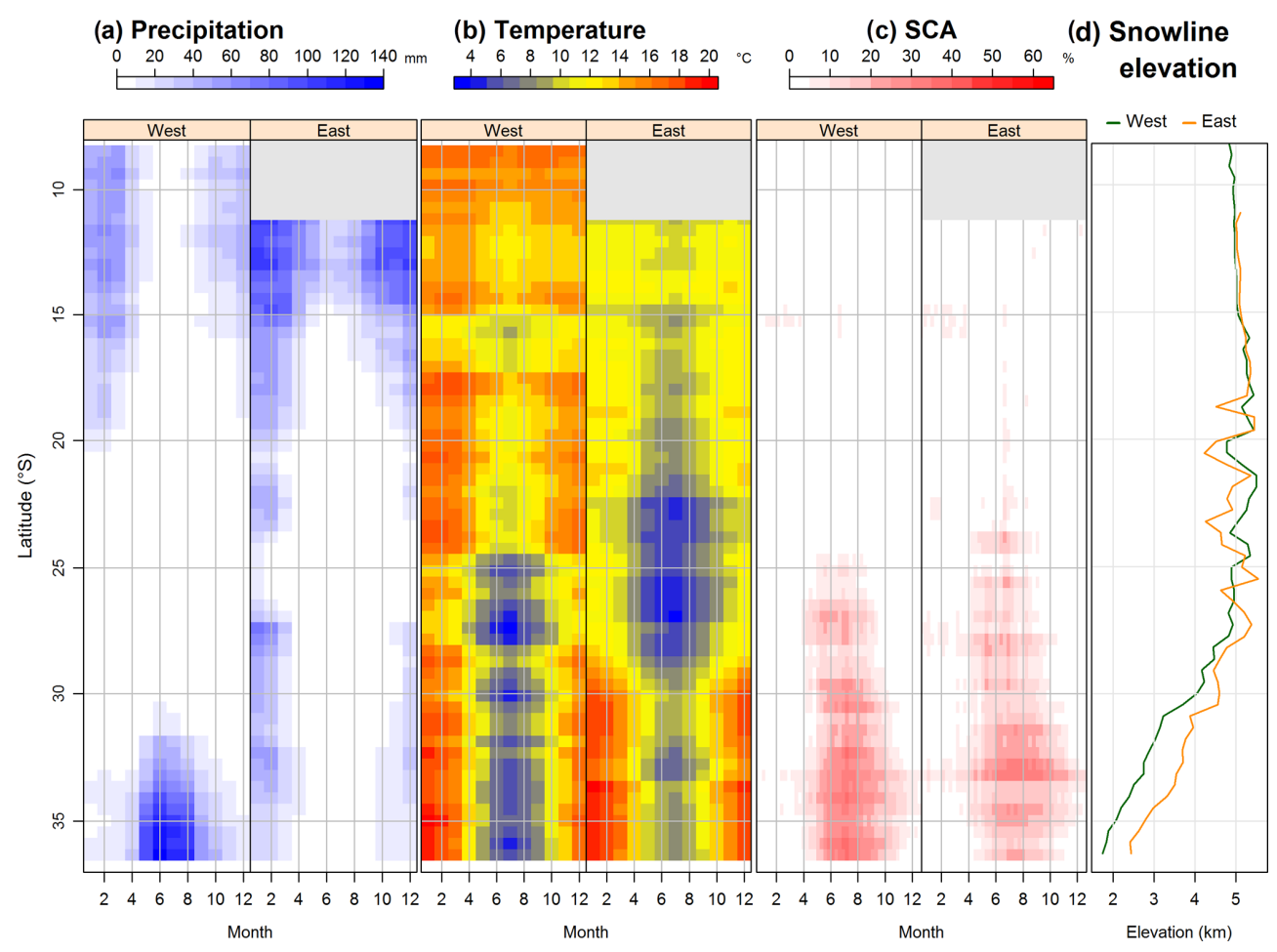

Figure 2. Mean monthly hydroclimate variables on the side of the continental divide (west-east) and latitude band for the period 2000-2016 for (a) precipitation and (b) temperature from the MERRA2 dataset, and (c) fraction of area with snow cover calculated from the binary 8-day product from MODIS (MOD10A2). (d) The snowline elevation (SP = 20\%) was derived using the methods of Saavedra et al. (2017). Gray areas represent latitudes masked due to high frequency of cloud cover in snow-covered area analysis ( $>30 \%$ time period).

monthly time step from https://climatedataguide.ucar.edu/. The Multivariate ENSO Index (MEI) is based on the six main observed variables (sea level pressure, zonal surface wind, meridional surface wind, sea surface temperature, surface air temperature, and total cloudiness fraction of the sky) over the tropical Pacific (http://www.esrl.noaa.gov/psd/enso/ mei/table.html) and has been described as a more complete and flexible description of the ENSO phenomenon (Wolter and Timlin, 1998). The Southern Oscillation Index (SOI) is a standardized index based on the observed sea level pressure differences between Tahiti and Darwin, Australia. The Oceanic Niño Index (ONI) calculates the anomalies of SST in Niño region 3.4 and is used as the standard index to defined Niño and Niña events by National Oceanic and Atmospheric Administration (NOAA). The Trans-Niño Index (TNI) is given by the difference in normalized anomalies of SST between Niño $1+2$ and Niño 4 regions. The Niño regions correspond to ship tracks and are defined as Niño $1+2\left(0-10^{\circ} \mathrm{S}, 90-80^{\circ} \mathrm{W}\right)$, Niño $3\left(5^{\circ} \mathrm{N}-5^{\circ} \mathrm{S}, 150-90^{\circ} \mathrm{W}\right)$, Niño $3.4\left(5^{\circ} \mathrm{N}-5^{\circ} \mathrm{S}, 170-120^{\circ} \mathrm{W}\right)$, and Niño $4\left(5^{\circ} \mathrm{N}-5^{\circ} \mathrm{S}\right.$, $\left.160^{\circ} \mathrm{E}-150^{\circ} \mathrm{W}\right)$.

Additionally, we explored the potential influence of the PDO on snow persistence (Dettinger et al., 2001; Masiokas et al., 2010) using the values available at https://www. ncdc.noaa.gov/teleconnections/pdo/. PDO is described as a long-lived El Niño-like pattern of Pacific climate variability (Zhang et al., 2016). We also evaluated the SAM because it affects South American precipitation by changing the position of the westerly wind belt that influences the strength and position of cold fronts and midlatitude storm systems (Gillett et al., 2006). We used the values available at http://www.esrl.noaa.gov/SAM/. SAM is a largely zonally symmetric mode of variability in the Southern Hemisphere computed from sea level pressure (Marshall, 2003).

We used a digital elevation model (DEM) developed based on Shuttle Radar Topographic Mission (SRTM) (at a $90 \mathrm{~m}$ resolution) and completed with Advanced Spaceborne Thermal Emission and Reflection Radiometer (ASTER) (at a $30 \mathrm{~m}$ resolution) elevation data (http://reverb.echo.nasa.gov/) in areas with missing SRTM values. We divided the study area into $100 \mathrm{~m}$ elevation bands and $0.5^{\circ}(\sim 50 \mathrm{~km})$ latitude bands (Saavedra et al., 2017). We changed the spatial resolution of MERRA2 and UDelv4 dataset by resampling to $500 \mathrm{~m}$ to fit with MOD10A2 spatial resolution. The continental divide was defined by using the drainage side (east or west) of the Andes determined from the watershed tool in ArcGIS $^{\circledR}$. All geospatial data were mosaicked and projected into the South American Albers equal area azimuthal projection to minimize shape distortion (Kennedy and Kopp, 1994). 


\subsection{Analysis}

To document snow cover patterns and their changes over time from 2000 through 2016, we calculated the annual SP for each $500 \times 500 \mathrm{~m}$ pixel in the study area as the fraction of the images in a year with snow cover (Saavedra et al., 2017). We masked areas with mean annual $\mathrm{SP}<7 \%$ to avoid potential misclassifications in MODIS snow products (Fig. 2a) (Hall et al., 2002). This threshold excludes the little to no snow zone (SP $<7 \%)$ as defined in Saavedra et al. (2017). For the remaining pixels we conducted all geostatistical analyses using the statistical computing R software (RCoreTeam, 2013). We used the mean annual SP time series 2000-2016 to capture the spatial-temporal variability of snow presence (Fig. S1a in the Supplement). We used the non-parametric Mann-Kendall analysis to test for trend significance in annual SP (Khaled and Ramachandra, 1998) and quantified the rate of change using the linear Theil-Sen slope, which determines the slope as the median of all possible slopes between data pairs (Theil, 1950; Sen, 1968). We ran the Mann-Kendall analysis using the "Kendall" package for R (McLeod, 2011). Trends were considered significant at a $p$ value $\leq 0.05$. We also calculated a standardized rate of change by dividing the original TheilSen slope by the mean annual SP. This allowed us to compare the rate of SP change (slope) in different snow zones. For each year, we used the annual SP to calculate the line with $\mathrm{SP}=20 \%$ (our definition of snowline). Then we applied a buffer function of $100 \mathrm{~m}$ over this line to create a band of $200 \mathrm{~m}$ width and calculated its mean elevation from the DEM (Saavedra et al., 2017). We evaluated the trends in snowline elevation for each $0.5^{\circ}$ latitude band on the west and east sides using Mann-Kendall analysis and calculated rates of change by the Theil-Sen slope. Finally, we calculated trends in SP for individual months and elevation bands and examined how the magnitude of trends varied seasonally and with elevation across the study area.

To explore how climate variables were related to SP trends we ran the same trend analyses described for SP on $P$ and $T$ to capture the spatial-temporal variability (Fig. S1b and c). Additionally, we evaluated the linear correlation between each climate variable $(P, T$, ENSO, PDO, and SAM at monthly and annual timescales) and SP using Pearson's correlation coefficient $(r)$. For the climate indexes (ENSO, PDO, and SAM), we examined how the index correlations with SP varied across the study area. To do this, we computed the absolute value of $r$ for each index value correlation with SP. Using only significant correlations, we then computed the sum of the absolute values of $r$ for all pixels in each of the snow regions defined by Saavedra et al. (2017) (tropical 1: 9-13 ${ }^{\circ} \mathrm{S}$; tropical 2: $13-24^{\circ} \mathrm{S}$; midlatitude 1: 24 $31^{\circ} \mathrm{S}$; and midlatitude $2: 31-36^{\circ} \mathrm{S}$ ). A greater value of this sum indicates higher correlations with SP across the region; for each region we identified the index that best predicts SP as the index with the greatest sum of absolute values of $r$.
Finally, we ran multiple linear regressions at an annual time step to define the proportion of variability of SP explained by each climate variable $(P, T)$. The strength of these regressions was quantified using the coefficient of determination $\left(r^{2}\right)$. Lastly, we calculated the relative importance of independent variables on annual SP using de Lindeman, Merenda, and Gold (LMG) approach included in the relative importance for multiple linear regression "relaimpo" $\mathrm{R}$ package (Groemping and Matthias, 2013). The LMG method evaluates the individual contribution of each regressor to the full $r^{2}$ of the model (Grömping, 2006). We visualized all statistical analyses by pixel mapping the geographic distribution of statistical output and by latitude-elevation charts to highlight the relationship with latitude and elevation ranges.

\section{Results}

\subsection{Annual snow persistence and snowline trends}

The mean annual SP across the Andes varies with both latitude and elevation (Fig. 3a). The total area with either intermittent, seasonal, or persistent snow (mean annual $\mathrm{SP} \geq 7 \%$ ) is $176284 \mathrm{~km}^{2}$ and is distributed in four main zones (Saavedra, 2016; Saavedra et al., 2017). The northern area (tropical $\left.1,9-13^{\circ} \mathrm{S}\right)$ has just $2 \%$ of this snow area $\left(3525 \mathrm{~km}^{2}\right)$; latitudes $13-24^{\circ} \mathrm{S}$ (tropical 2) contain $12 \%\left(21154 \mathrm{~km}^{2}\right)$ of the snow area; latitudes $24-31^{\circ} \mathrm{S}$ (midlatitude 1) contain $41 \%$ $\left(72277 \mathrm{~km}^{2}\right)$, and the remaining $45 \%$ of snow-covered areas are all between 31 and $36^{\circ} \mathrm{S}$ (midlatitude 2, $79328 \mathrm{~km}^{2}$ ). Mann-Kendall trend analyses of annual SP (Fig. 3b) show significant decreasing trends south of $29^{\circ} \mathrm{S}$, where $2-5$ fewer days of snow every year $\left(-1.5\right.$ to $-0.5 \%$ year $\left.^{-1}\right)$ are the most common values. Small areas registered an increase of $\mathrm{SP}$ (blue range colors in Fig. 3b) south of $34^{\circ} \mathrm{S}$ at lower elevations. The standardized rate of change shows the magnitude of the rate of change normalized by mean annual SP (Fig. 3c). North of $34^{\circ} \mathrm{S}$ the standardized rate of changes is elevation-dependent on both sides of the mountains, with greater changes (more negative trends) at lower SP values. South of $34^{\circ} \mathrm{S}$ the relative changes in SP are greater (more negative) on the east side than on the west side of the Andes. As a result of the short period of study, we computed the trend of cloud cover to evaluate whether changes in the frequency of clouds could have generated spurious trends. We did not detect any significant trends in cloud frequency in the study area (data not shown), indicating that trends in cloud impairment would likely not have influenced the detected SP trends.

The latitude-elevation band analysis of SP reveals how the pattern of snow varies with elevation across the region (Fig. 4a). North of $23^{\circ} \mathrm{S}$ the snow is confined to over $5000 \mathrm{~m}$, with a steep change of SP with elevation. South of $26^{\circ} \mathrm{S}$, areas with similar SP values are found at lower elevations with increasing latitude. The west side has consistently lower- 
(a) Snow persistance (SP)

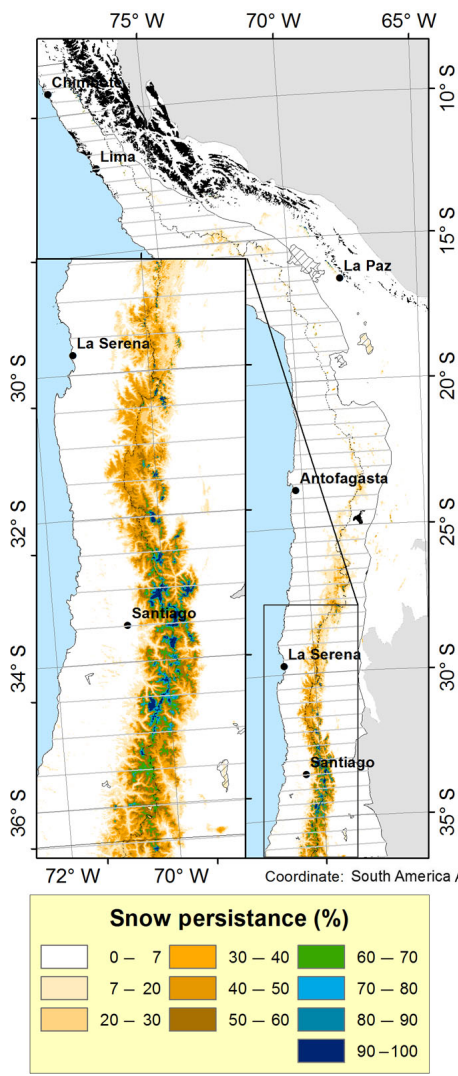

(b) SP rate of change (SPCH)
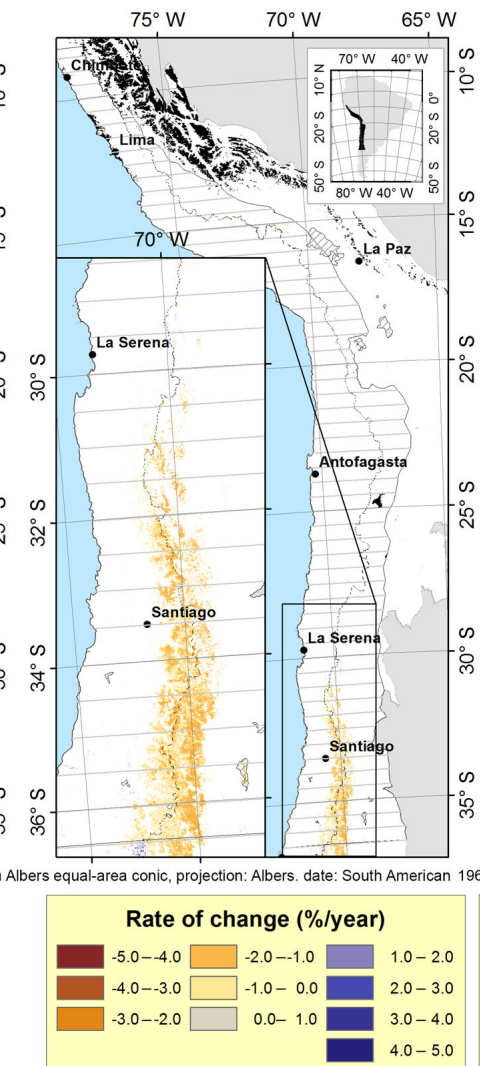

(c) Standardized SPCH

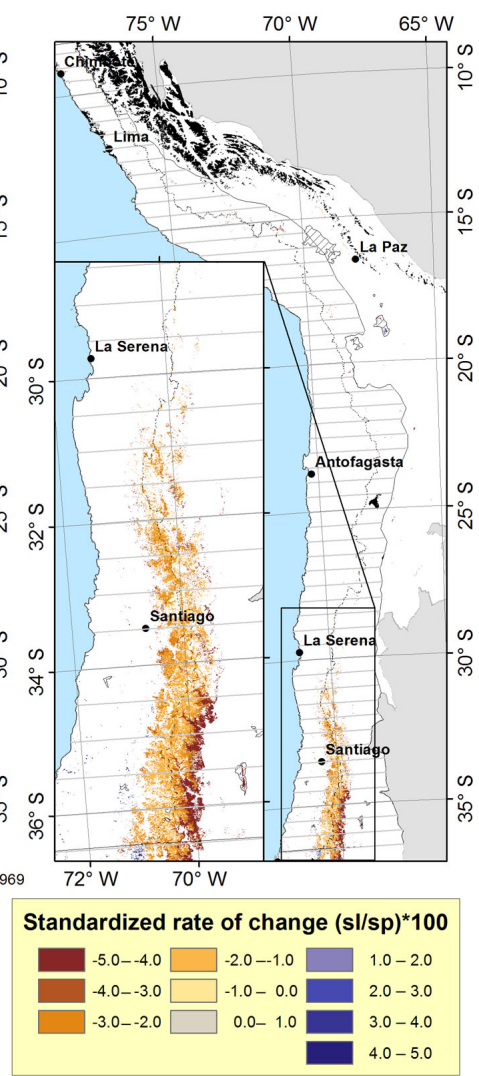

Figure 3. Spatial patterns of (a) snow persistence (SP) 2000-2016, (b) rate of change (Theil-Sen slope) in annual SP 2000-2016, and (c) standardized rate of change (Theil-Sen slope/SP); pixels are only colored in panels (b) and (c), where the trend is significant at $p \leq 0.05$. All images exclude areas with little to no snow (mean annual SP $\leq 7 \%$ ). Areas with frequency of cloud greater that $30 \%$ are masked in black.

elevation snow than the east side for any value of SP under $90 \%$ (Fig. 4d). For a more detailed description of these patterns see Saavedra et al. (2017). North of $19^{\circ} \mathrm{S}$, decreasing SP is confined to over $5000 \mathrm{~m}$ on both sides of the Andes (Fig. 4b). South of $29^{\circ} \mathrm{S}$, areas with declining SP occur at lower elevation and vary between west and east sides. The west side has a lower elevation of each category of the Theil-Sen rate of change compared to the east side at the same latitude. The maximum rates of decreasing SP are located at middle-high elevations, between 4000 and $5000 \mathrm{~m}$ at $29^{\circ} \mathrm{S}$ and between 3000 and $4000 \mathrm{~m}$ at $36^{\circ} \mathrm{S}$ for both sides (Fig. 4b). The maximum rates of SP decline are in the seasonal snow zone, which is defined as mean annual SP between 30 and $90 \%$ (Fig. 4e) (Saavedra et al., 2017). In contrast, the standardized Theil-Sen rate of change shows greater declines at lower values of SP on both sides, except in a few anomalous areas (Fig. 4c). This means that the greatest relative declines in SP occur in the intermittent snow zone (Fig. 4f).

The amount of area affected by significant changes in SP also shows a strong difference between the west and east sides of the Andes (Fig. 5a). South of $29^{\circ} \mathrm{S}$ the total area with Theil-Sen slopes lower (more negative) than -0.5 $\left(\%\right.$ year ${ }^{-1}$ ) is $34370 \mathrm{~km}^{2}$. The majority $(62 \%)$ of this area is on the east side of the Andes. The most common change values are on the order of -2.0 to $-0.5 \%$ year $^{-1}$. For areas with the steepest declining trends in SP $\left(-3.0\right.$ to $-2.5 \%$ year $\left.^{-1}\right)$, $79 \%$ of the affected area is east of the continental divide (Fig. 5d). Trends in snowline elevation (elevation of $20 \%$ SP) were only significant south of $29^{\circ} \mathrm{S}$ on the west side and south of $30^{\circ} \mathrm{S}$ on the east side of the range (Fig. 5b), where the snowline increased in elevation at a rate of about 10-30 mear $^{-1}$. Rates of increase in snowline elevation are higher for the west side than for the east side between 30 and $32^{\circ} \mathrm{S}$, but south of $34^{\circ} \mathrm{S}$ the east side snowline elevation changes are higher and significant compared with a nonsignificant trend on the west side.

North of $23^{\circ} \mathrm{S}$ the greatest changes in SP were in austral fall (March to May, months 1-3 in Fig. 5c) on both side of the Andes (Fig. $5 \mathrm{e}-$ tropical). South of $23^{\circ} \mathrm{S}$, the largest changes were in late austral winter (August, month 8 in Fig. 5c) for the intermittent snow zone (Fig. 5e - extratropical), where no major differences in the seasonality of change between west and east sides were observed. For the seasonal snow zone, the 


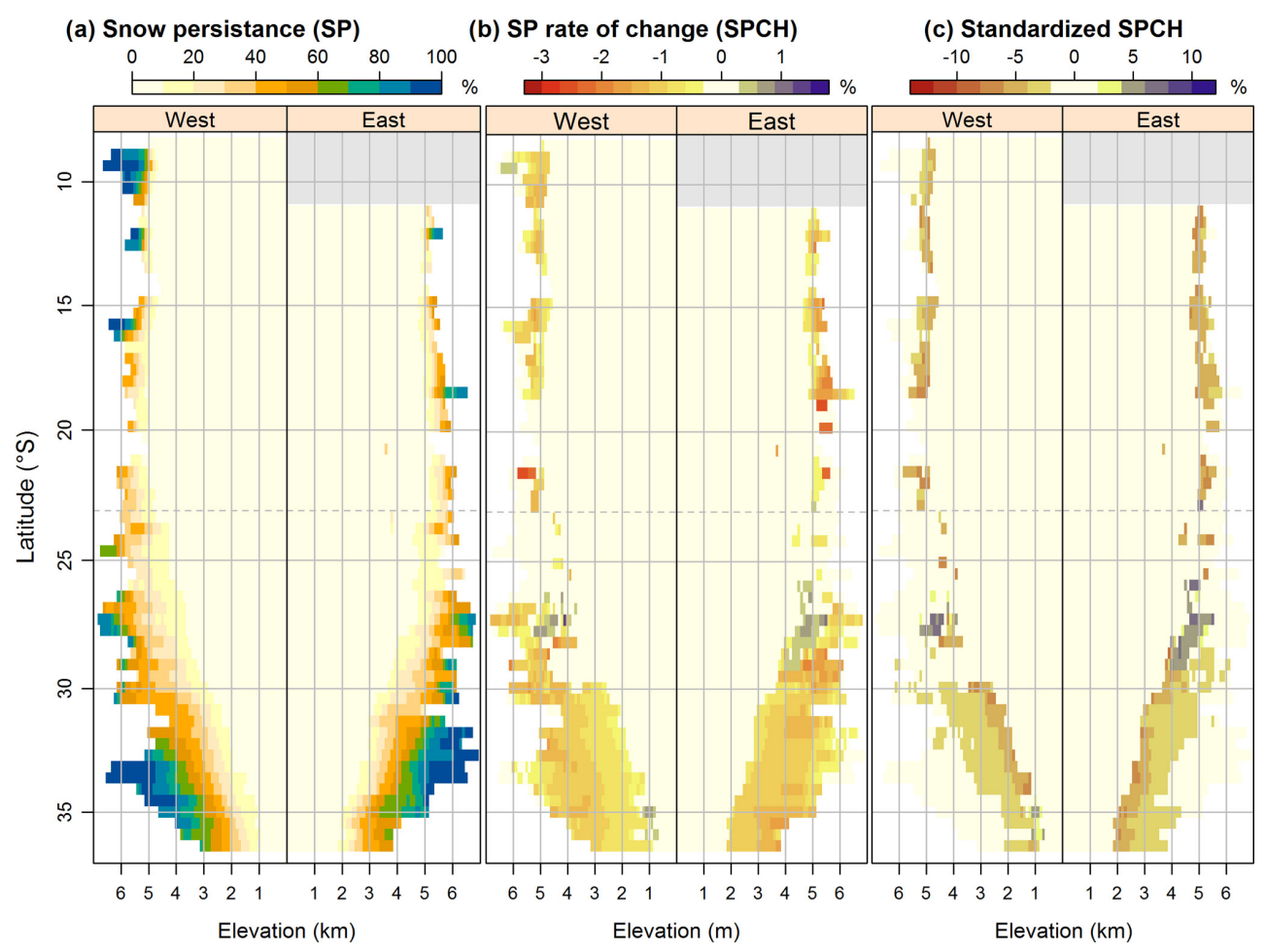

(d) SP curves

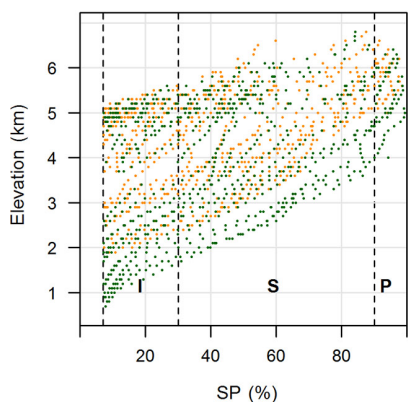

(e) SPCH vs. SP

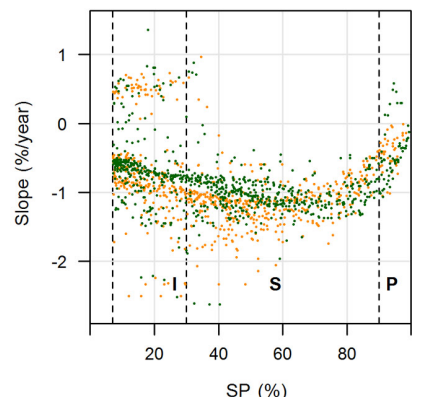

(f) Standardized SPCH vs. SP

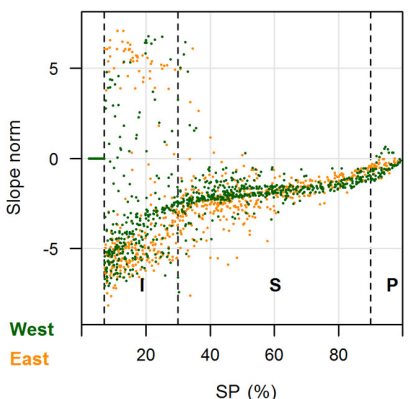

Figure 4. Latitude-elevation band analysis by side of the continental divide (west-east) for (a) mean annual SP, (b) rate of change (Theil-Sen slope) from the Mann-Kendall trend test for annual SP, and (c) standardized rate of change from 2000 to 2016 ; only areas with significant trends $(p \leq 0.05)$ and $\mathrm{SP} \geq 7 \%$ are colored. Gray areas in panels $(\mathbf{a}, \mathbf{b}, \mathbf{c})$, represent latitudes masked due to high frequency of cloud cover in snow-covered area analysis ( $>30 \%$ time period). The SP curves in plot (d) show the relation of SP with elevation. The relation between SP and Theil-Sen slope is shown in plot (e), and standardized Theil-Sen slope in plot (f). West (green) and east (orange) sides are plotted in panels $(\mathbf{d}, \mathbf{e}, \mathbf{f})$; vertical dashed gray lines represent thresholds for intermittent $(\mathrm{I})$, seasonal $(\mathrm{S})$, and persistent $(\mathrm{P})$ snow zones $($ Saavedra et al., 2017).

largest changes in SP were during the melting season in austral late winter-early spring (August to October, months 8 to 10 in Fig. 5c). Finally, at the upper boundary of the seasonal snow zone and into the persistent snow zone (SP $>70 \%)$, the largest changes in SP were observed during austral fall.

\subsection{Climate connection}

Many portions of the study area had significant trends in both annual precipitation and mean annual temperature from 2000 to 2016 (Fig. 6). Trends in annual precipitation were pri- marily not significant north of $20^{\circ} \mathrm{S}$, whereas they showed a significant decrease from $2-4 \mathrm{~mm}_{\text {year }}{ }^{-1}$ at $28^{\circ} \mathrm{S}$ to 15 $25 \mathrm{~mm} \mathrm{year}^{-1}$ at $30-36^{\circ} \mathrm{C}$ (Fig. 6a) on the west side of the continental divide. The standardized decrease of precipitation (Theil-Sen slope/mean annual $P$; Fig. 6b) was low north of $31^{\circ} \mathrm{S}(1 \%)$ and increased to the south, with higher values on the west side of the range. This indicates greatest impacts of decreasing precipitation on the west side. The seasonality of decreasing $P$ (Fig. 6c) shows that the austral winter (JJA) was the most affected season on the west side, 
(a) Area affected

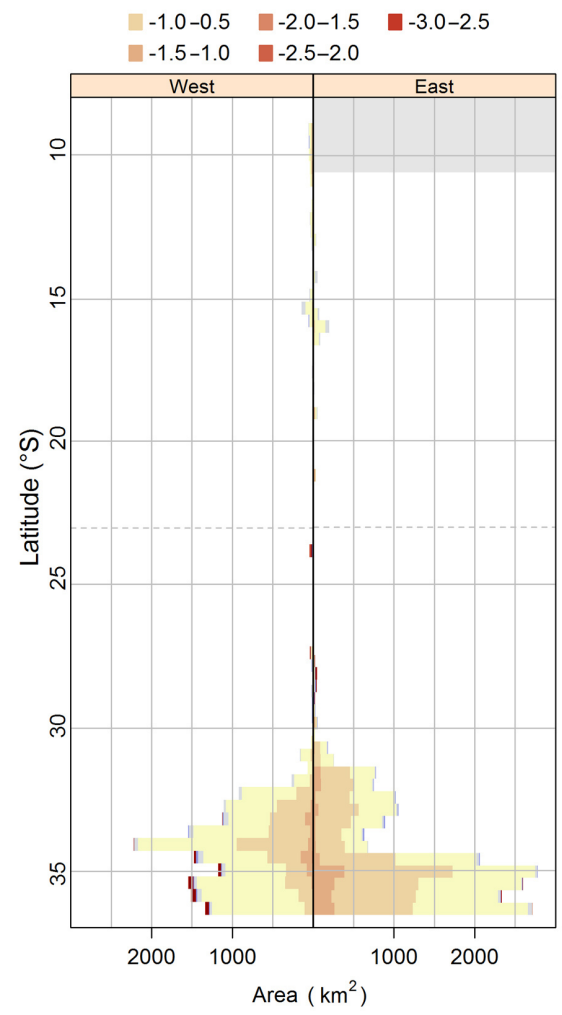

(b) Snowline elevation

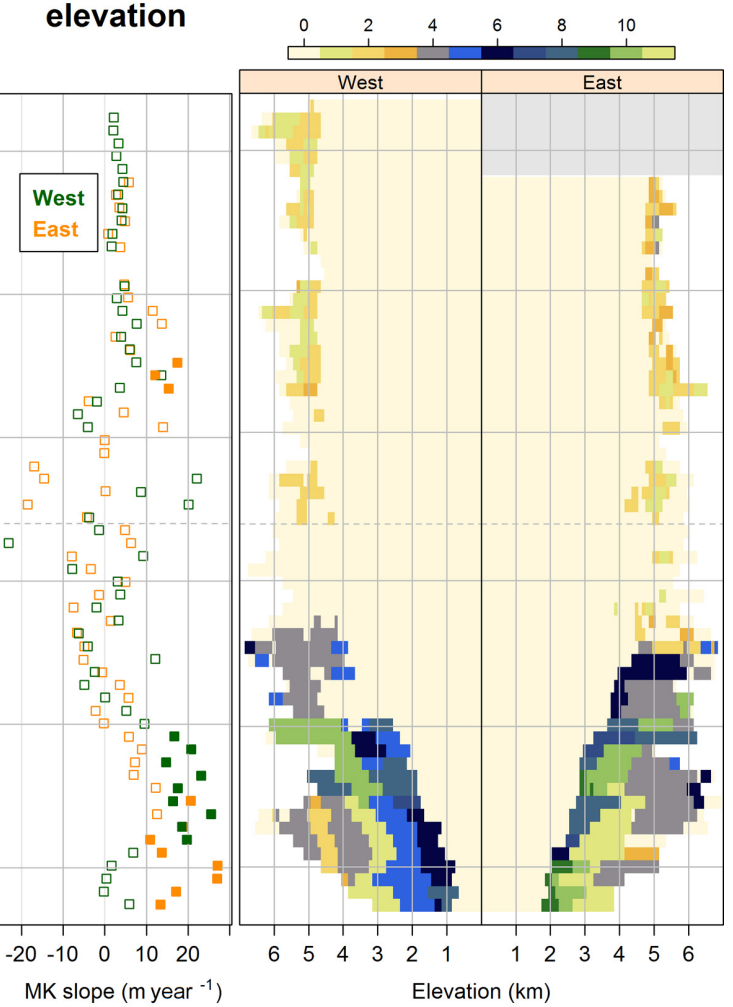

(d) Area south of $23^{\circ} \mathrm{S}$

(e) Month vs. SP
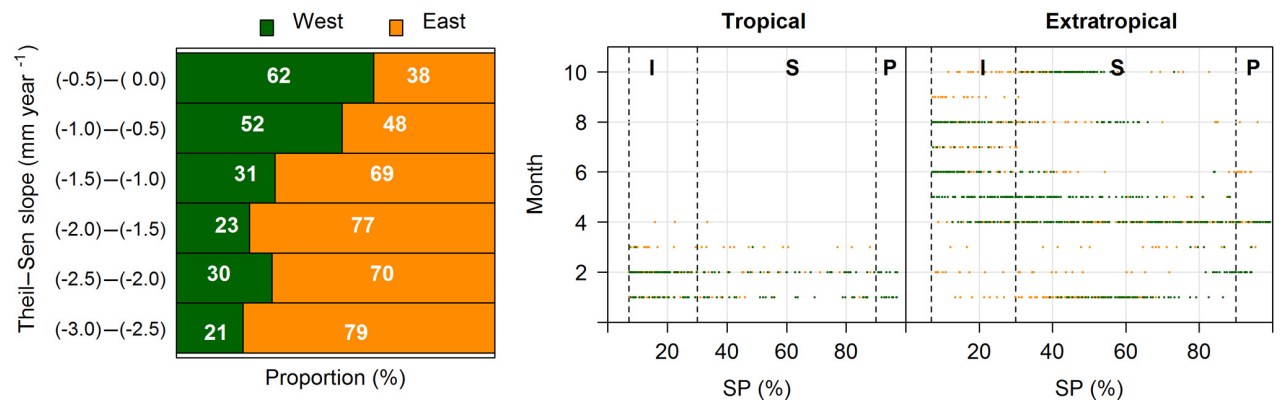

Figure 5. (a) Areas with significant trends in annual SP by side of the continental divide (west-east) and latitude band; (b) rate of change (Theil-Sen slope) in the elevation of the snowline $(\mathrm{SP}=20 \%)$, where solid symbols have significant trends $(p \leq 0.05)$; (c) months with the highest significant Theil-Sen slope from the Mann-Kendall trend analysis of monthly SP; (d) percent of area in each Theil-Sen slope category for west and east sides; and (e) months with greatest SP rate of change (slope) in tropical (north of $23^{\circ} \mathrm{S}$ ) and extratropical (south of $23^{\circ} \mathrm{S}$ ) latitudes for west (green) and orange (east) sides of the continental divide. Vertical dashed gray lines in panel (e) represent thresholds for intermittent (I), seasonal (S), and persistent (P) snow zones.

and early austral fall (March) was most affected on the east side.

Temperature increased significantly north of $20^{\circ} \mathrm{S}$ on both sides of the Andes in the range of 0.04 to $0.08^{\circ} \mathrm{C}_{\text {year }}{ }^{-1}$ (Fig. 6d). In most of the rest of the study area, temperatures had increasing trends or no trends detected. A large area with significant increasing trends extended from 31 to $36^{\circ} \mathrm{S}$ on the west side and $26-36^{\circ} \mathrm{S}$ on the east side. The standardized change of temperature (Theil-Sen slope / mean annual temperature) shows highest values north of $20^{\circ} \mathrm{S}(5-$ $15 \%)$ and a lower rate of increase $(0.2-5 \%)$ from 31 to $36^{\circ} \mathrm{S}$ (Fig. 6e). The seasonality of increasing temperature trends varied across the region (Fig. 6f). North of $15^{\circ} \mathrm{S}$ the highest increase occurred in June, and south of $26^{\circ} \mathrm{S}$ the greatest increases were mainly in fall months.

Examples of climate variability across the region are illustrated in latitude bands 15,33 , and $36^{\circ} \mathrm{S}$ in Fig. 7. The latitudinal bands selected (Fig. 7c-e) show a significant increase 

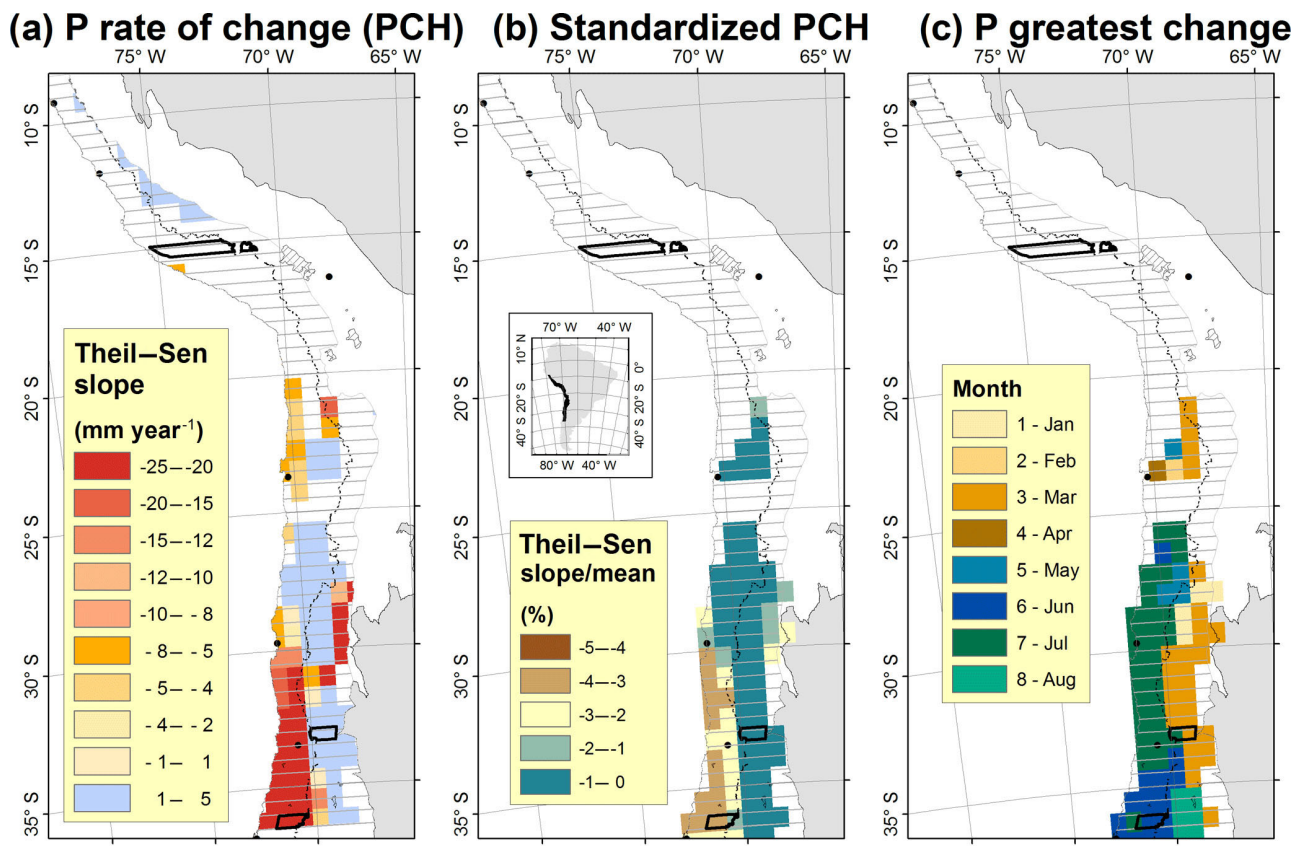

\section{$\begin{array}{lll}\text { (d) } \mathrm{T} \text { rate of change }(\mathrm{TCH}) & \text { (e) Standardized } \mathrm{TCH}\end{array}$}
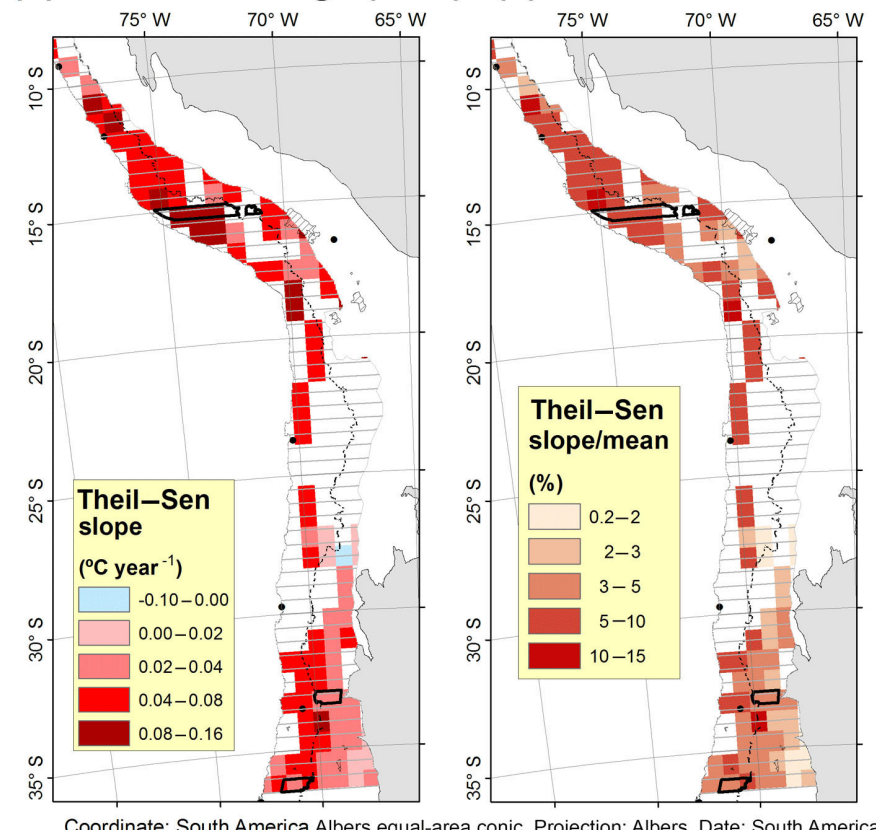

\section{(f) T greatest change}

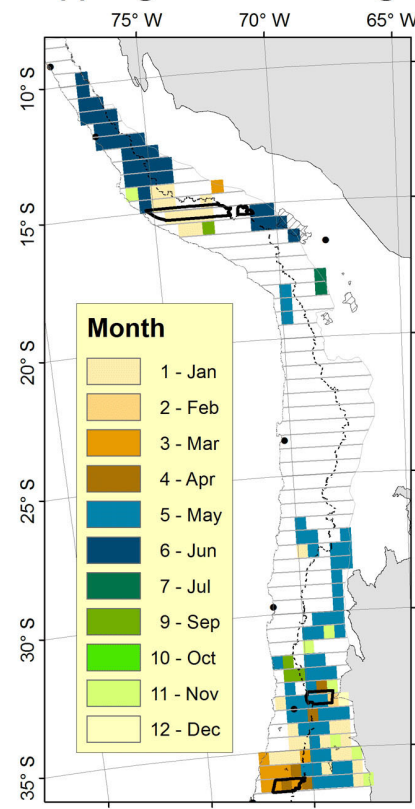

$$
\text { - City Water bodies ........- Continental divide } \square \text { Selected bands }
$$

Figure 6. The Theil-Sen rate of change over the period 2000 to 2016, standardized Theil-Sen slope, and month of the greatest change (largest increase of temperature or largest decrease of precipitation) at an annual timescale for precipitation $(P)(\mathbf{a}, \mathbf{b}, \mathbf{c})$ and air temperature $(T)(\mathbf{d}, \mathbf{e}, \mathbf{f})$; only pixels with significant trends $(p \leq 0.05)$ are colored. Black polygons highlight selected latitude bands used to describe in detail the evolution of temperature, precipitation, and snow from 1960 to 2016 (Fig. 7).

of temperature in both periods, 1960-2016 and 2000-2016, except in the tropical band (Fig. 7c) where the increase was not significant. Precipitation had a non-significant increase for the northern bands (Fig. 7c-d) and a non-significant de- crease in the southern band (Fig. 7e) for the period 1960 2016. After 2000, all bands showed a decrease of $P$, but this was only significant in the southern band (Fig. 7e). SP 


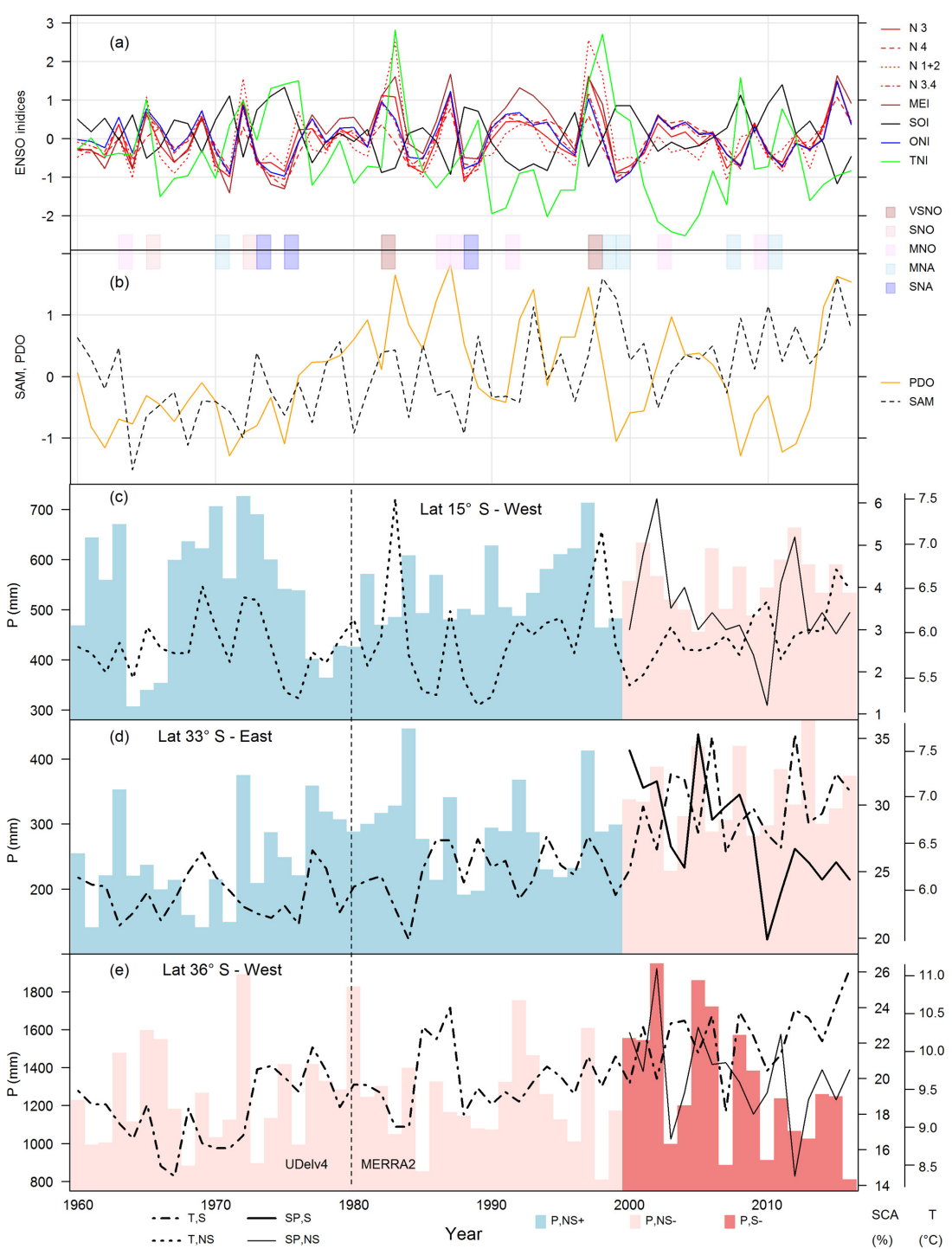

Figure 7. Comparison of the study time period (2000-2016) with the longer period of record since 1960. (a) Time series of ENSO indices of Niño events (Niño 3 (N 3), Niño 4 (N 4), Niño 1+2 (N 1+2), Niño 3.4 (N 3.4), Multivariate ENSO Index (MEI), Southern Oscillation Index (SOI), Oceanic Niño Index (ONI), and Trans-Niño Index (TNI)), (b) Pacific Decadal Oscillation (PDO), and Southern Annular Mode (SAM). Colored columns between panels (a) and (b) represent Niño events based on the ONI index, i.e., very strong Niño (VSNO), strong Niño (SNO), moderate Niño (MNO), moderate Niña (MNA), and strong Niña (SNA). Plots (c-e) show selected latitude bands (Fig. 6). Time series of temperature show a non-significant increase (dashed line; $T$, NS) and significant increase (point-lined line; $T, \mathrm{~S}$ ) from UDelv4 and MERRA2 datasets. Precipitation (solid column) has non-significant increase in light blue $(P, \mathrm{NS}+)$ (pink is $P$, NS-) and significant trend in bold colors $(P, \mathrm{~S}-)$ from UDelv4 and MERRA2 datasets. The annual average SCA from MODIS dataset as percentage of whole latitude band from 2000 to 2016 is represented, where a thick line (SP, S-) indicates significance and a thin line is insignificance (SP, NS+). The vertical dashed line in plots (c-e) shows the time change from UDelv4 to MERRA2 datasets.

showed decreases in all bands, but just the middle band was significant (Fig. 7d).

ENSO (Fig. 7a), PDO, and SAM indices (Fig. 7b) show a cyclical pattern between 1960 and 2016. ONI is the primary indicator from NOAA for monitoring El Niño and La Niña events. NOAA categorizes an El Niño event when five consecutive 3 -month running mean values of ONI are +0.5 or higher (warm phase) and a La Niña event when this value is -0.5 or lower (cold phase). Based on ONI values, very strong Niño events were defined in 1982-1983 and 19971998 and strong Niño in 1965-1966 and 1972-1973. Strong Niña events were defined in 1973-1974, 1975-1976, and 1988-1989 (colored column between Fig. 7a and b).

All SST indices (Niño 3, 4, 1+2, and 3.4) and MEI generally have similar patterns to the ONI index, with negatives values in La Niña events and positive in El Niño events (red 
(a) Air temperature, $\mathrm{T}$

(b) Precipitation, $\mathbf{P}$

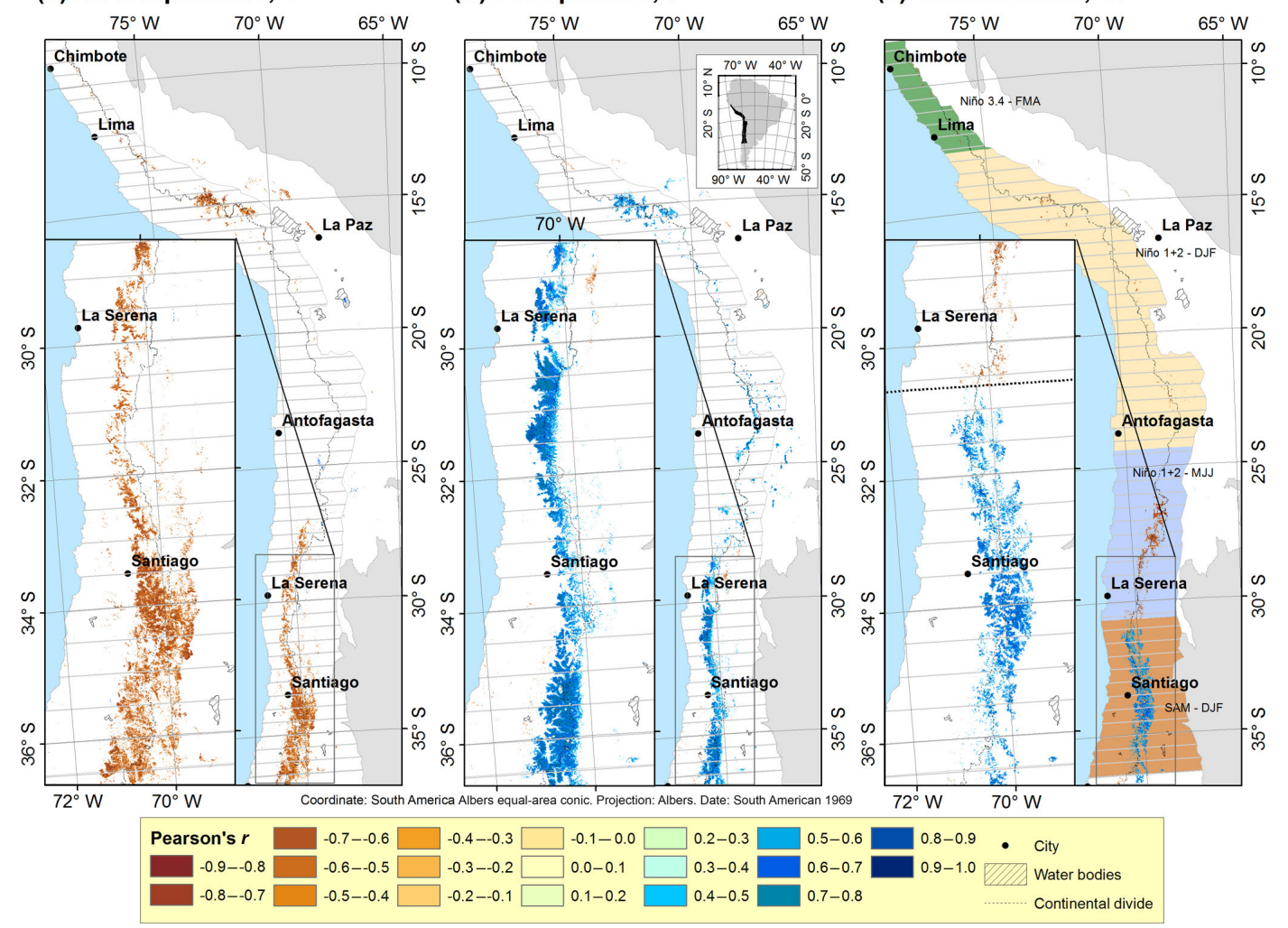

Figure 8. Map of Pearson's correlation coefficient ( $r$ ) between 2000 and 2016 annual SP and (a) mean annual temperature, (b) annual total precipitation, and (c) the best climate index and the 3-month time window that had strongest correlations with SP in each region. Time windows give the range of months over which the climate index was averaged, expressed by first letter of each month. DJF is December, January, February; FMA is February, March, April; MJJ is May, June, July.

lines in Fig. 7a). Prolonged periods of negative SOI values coincide with El Niño episodes, and positive values coincide with La Niña episodes. TNI high values relate to the very strong El Niño events (82-83 and 97-98), but negative values were not related to La Niña episodes (73-74, 75-76, and 88-89). Additionally, long periods of negative TNI (89-90 to $97-98$ and $00-01$ to $07-08$ ) were not related to La Niña events defined with the previous indices. The PDO, which describes a different climate pattern from ENSO, showed a longer cycle than ENSO indices. Some positive values were associated with very strong El Niño events (82-83 and 9798 ), but other high positive values were not related to El Niño events (92-93) (Fig. 7b). SAM showed a long cycle and presented negative values in La Niña events (73-74 and 75-76) and positive values with El Niño events (82-83 and 97-98) (Fig. 7b).

Correlations between annual SP and air temperature, precipitation, and the best climate index by snow region vary across the length of the Andes (Fig. 8). The climate index selected to correlate with each snow region is the index and month with the greatest integrated correlation across the region (Fig. S2). The highest integrated correlations per region were El Niño 3.4 centered in March (FMA) for north of $12^{\circ} \mathrm{S}$ (tropical 1), El Niño $1+2$ in January (DJF) for $2-24^{\circ} \mathrm{S}$ (tropical 2), El Niño $1+2$ centered in June (MJJ) for $24-31^{\circ} \mathrm{S}$ (midlatitude 1), and SAM centered in January (DJF) for areas south of $31^{\circ} \mathrm{S}$ (midlatitude 2). Table 1 presents a summary of the best indices by snow regions.

Air temperature, precipitation, and climate index were correlated with SP in some portions of the study area; however, patterns and relationships varied regionally. Both temperature and precipitation were significantly correlated with SP at around $15^{\circ} \mathrm{S}$ and south of $28^{\circ} \mathrm{S}$ (Fig. 8a, b). For air temperature the relationship with SP was inverse except at a few high elevations $(>5000 \mathrm{~m})$ (Fig. 9a), and the strength of the correlation was greatest in the intermittent snow zone (Fig. 9d). Precipitation had a direct correlation with SP in almost all places where the correlation was significant (Fig. 9b). The strength of this correlation varied with SP in extratropical areas (Fig. 9e), with the strongest correlations occurring in the seasonal snow zone. The correlations of SP with climate indices were mostly negative north of $31^{\circ} \mathrm{S}$, where ENSO indices were used, and positive south of this latitude, where SAM was used as the climate index (Figs. 8c, 9c). These correlations did not have a clear pattern with change of SP in the 
Table 1. Top ranking climate indices for predicting SP by snow region, indicating the average correlation $\left(r_{\mathrm{avg}}\right)$ and the sum of the absolute values of $r$ for each snow region $\left(\sum|r|\right)$.

\begin{tabular}{lcrllrrr}
\hline $\begin{array}{l}\text { Snow } \\
\text { region }\end{array}$ & $\begin{array}{r}\text { Latitude } \\
\text { range }\end{array}$ & Ranking & Index & Month & $\begin{array}{r}\text { Area } \\
\left(\mathrm{km}^{2}\right)\end{array}$ & $r_{\text {avg }}$ & $\sum|r|$ \\
\hline \multirow{2}{*}{ Tropical 1 } & \multirow{2}{*}{$9-13^{\circ} \mathrm{S}$} & 1 & Niño 3.4 & FMA & 275 & -0.63 & 711 \\
& & 2 & Niño 4 & DJF & 254 & -0.61 & 653 \\
& 3 & ONI & DJF & 248 & -0.61 & 639 \\
\hline \multirow{2}{*}{ Tropical 2 } & $13-24^{\circ} \mathrm{S}$ & 1 & Niño 1+2 & DJF & 1277 & -0.60 & 3122 \\
& & 2 & Niño 3 & DJF & 408 & -0.57 & 945 \\
& & 3 & Niño 1+2 & FMA & 287 & -0.44 & 829 \\
\hline \multirow{3}{*}{ Midlatitude 1 } & $24-31^{\circ} \mathrm{S}$ & 1 & Niño 1+2 & MJJ & 6160 & -0.61 & 15272 \\
& & 2 & Niño 1+2 & JJA & 3863 & -0.59 & 9171 \\
& & 3 & Niño 1+2 & JAS & 3426 & -0.59 & 8161 \\
\hline \multirow{2}{*}{ Midlatitude 2 } & $31-36^{\circ} \mathrm{S}$ & 1 & SAM & DJF & 17790 & 0.59 & 42511 \\
& & 2 & SOI & AMJ & 16402 & -0.60 & 39480 \\
& & 3 & Niño 1+2 & DJF & 5465 & -0.56 & 12319 \\
\hline
\end{tabular}

tropical latitudes but were highest in the seasonal snow zone in extratropical latitudes (Fig. 9f).

To examine the combined influences of precipitation and temperature on annual SP, we ran a coefficient of determination $\left(r^{2}\right)$ analysis using $P$ and $T$ as predictors (Fig. 10a). We excluded climate index from this analysis because of its correlation with $P$ and $T$. Areas south of $28^{\circ} \mathrm{S}$ had significant and strong coefficient of determination $\left(r^{2}\right)$ values $\left(27530 \mathrm{~km}^{2}\right)$. Around $75 \%$ of the area with significant $r^{2}$ had values between 0.4 and 0.7 . To explore which parameter (air temperature or precipitation) most influenced SP in each location, we computed the relative importance of each variable in multiple linear regressions (Fig. 10b). Precipitation was the most important predictor across much of the region except from around 33 to $34.5^{\circ} \mathrm{S}$ and at the lower elevations of each affected region.

High values of $r^{2}$ north of $25^{\circ} \mathrm{S}$ are found at high elevations $(>5000 \mathrm{~m})$, and south of this latitude high $r^{2}$ values are found at lower elevations and show an elevation dependence in the midlatitude 2 region (Fig. 11a). The maximum $r^{2}$ values in the midlatitude 2 region are generally in the seasonal snow zone on the west side (Fig. 11c). The relative importance plot shows a clear importance of $T$ in tropical areas (north of $15^{\circ} \mathrm{S}$ ) and at lower elevations south of $26^{\circ} \mathrm{S}$ on the west side. The highest relative importance of $P$ was in the seasonal snow zones, whereas the relative importance of $T$ increased in intermittent and persistent snow zones (Fig. 11d).

\section{Discussion}

The range of spatial and temporal snow patterns during the period analyzed provide important insights about snow patterns and how they relate to temperature and precipitation during the period of the analysis. However, we note that the main limitation of our study is the short time period of the study (2000-2016), so the trends presented should not be considered representative of long-term climate trends (> 30 years). This study provides a basis for future studies testing longer-term relationships of spatiotemporal tends in snowpack with broad-scale climate drivers and with weather and climate variability in the region.

\subsection{Spatial variability in snow persistence trends}

SP trends varied across the study area. North of $25^{\circ} \mathrm{S}$, the snow-covered areas are small, making it difficult to track trends in SP (Fig. 3a). This low snow presence is likely due to a combination of temperature and precipitation effects. Precipitation is concentrated during the austral summer, synchronous with the highest temperatures of the year (Fig. 2a and $b$ ). Thus, precipitation falls mostly as rain, and snow is limited to elevations $>5000 \mathrm{~m}$ (Fig. $4 \mathrm{a}$ ), where temperature is generally cold. The limited trend is SP in this area (Figs. 3b and $4 \mathrm{~b}$ ) is likely because SP variability is more strongly related to precipitation than to temperature (Fig. 11b), and few trends in precipitation were detected in those areas (Fig. 6a).

South of $25^{\circ} \mathrm{S}$, we detected a significant decrease of SP (Fig. 3b). The rates of decline varied across the range of elevation and latitudes. Areas with intermittent winter snow showed a moderate decrease $(-0.5$ to $-1.0 \%$ per year) (Fig. 4e), with the largest decrease during winter (Fig. 5c). However, these areas had the largest relative rates of snow loss (standardized slope in SP) (Fig. 4c, f), particularly on the east side of the Andes. Low-elevation snowpack is often found to be most sensitive to climatic change, yet we found that areas with seasonal winter snow showed the steepest absolute rate of change $(-1.5 \%$ per year) around $\mathrm{SP}=60 \%$ (Fig. 4e). Elevation variability in snow trends 
(a) Air temperature, $\mathrm{T}$

(b) Precipitation, $\mathrm{P}$

(c) Climate index, $\mathrm{Cl}$

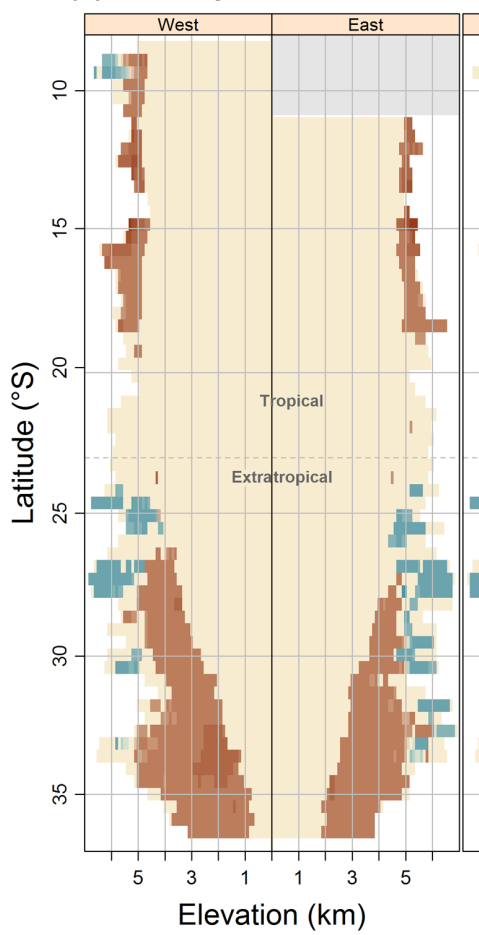

\section{West}

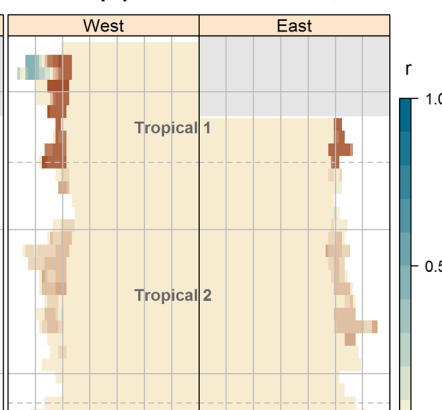

(d) T vs. SP

(e) P vs. SP

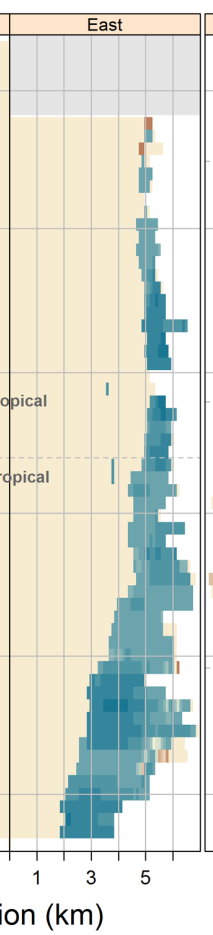

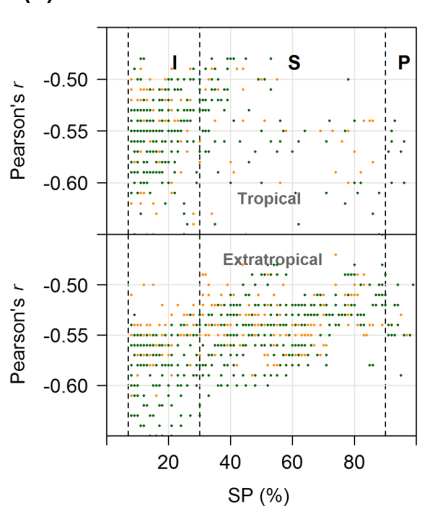
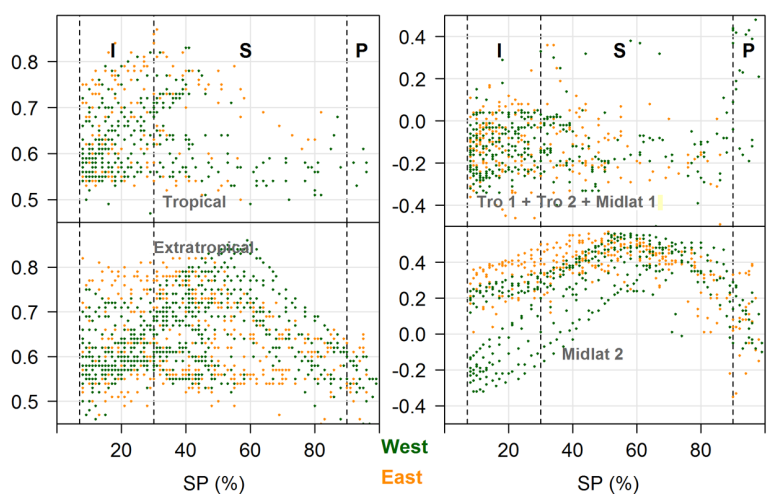

Figure 9. Latitude-elevation band analysis by side of the continental divide (west-east) for Pearson's correlation coefficient $(r)$ between annual snow persistence and (a) air temperature, (b) precipitation, and (c) climate indices. Gray areas represent latitudes masked due to the high frequency of cloud cover in snow-covered area analysis (>30\% period). Plots (d), (e), and (f) show values for each latitude-elevation band change by SP in west (green) and east (orange) sides. Vertical dashed gray lines represent thresholds for intermittent (I), seasonal (S), and persistent $(\mathrm{P})$ snow zones.

was also present in the San Francisco estuary and its upstream watershed (California, USA), where the greatest loss of snowpack was identified in the $1300-2700 \mathrm{~m}$ elevation range (Knowles and Cayan, 2004) in the seasonal snow zone (Moore et al., 2015). This spatial variability in snow trends with elevation, latitude, and side of the mountain range demonstrates the importance of spatial information for documenting snow change; trends identified at specific field sites may not be representative of the region as a whole (Fassnacht et al., 2016).
Loss of snow in the intermittent snow zone affected the trend of snowline elevation. Increases in snowline elevation have been documented in Andes tropical areas for the 19612012 time period (Pepin et al., 2015). However, our work does not show an increase in snowline in tropical areas, probably due to the short period of record, precipitation dependence of snow cover in this area (Saavedra et al., 2017), and the lack of consistent precipitation trends in these latitudes over the 2000-2016 period (Fig. 6a). In the central area (32-34 $\left.{ }^{\circ} \mathrm{S}\right)$, Carrasco et al. (2008) found an increase of elevation of isotherm $0^{\circ} \mathrm{C}$ of $23 \mathrm{~m}_{\text {year }}{ }^{-1}$ that is consistent in 
(a) Regression T \& P

(b) Relative importance T \& P

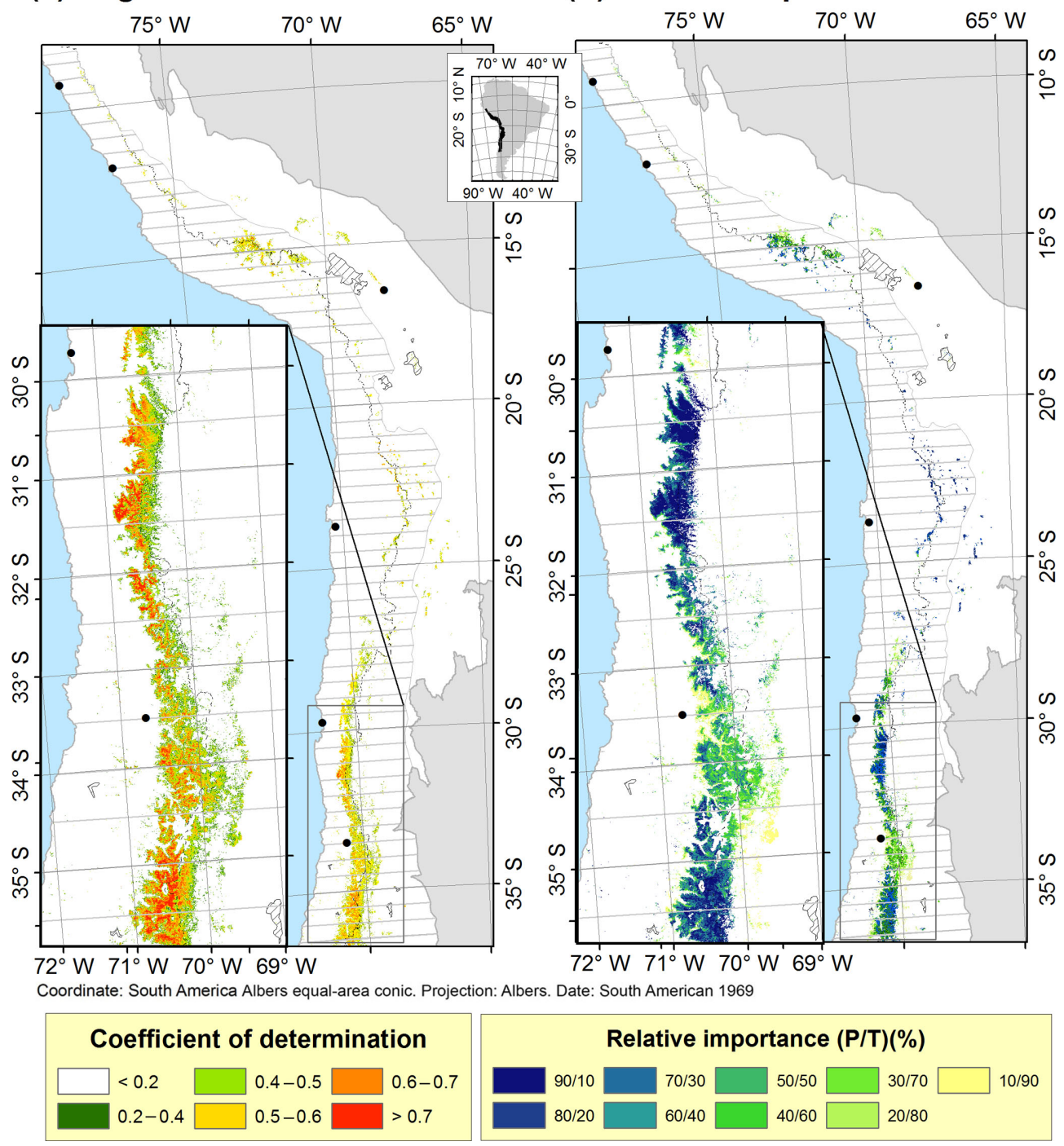

Figure 10. Multiple linear regression analysis by pixel showing (a) the coefficient of determination $\left(r^{2}\right)$ for SP predictions using annual precipitation and mean annual air temperature and (b) relative importance (RI), indicating the proportion of $(P / T)$ individual contribution of precipitation to the full $r^{2}$ of the model.

both magnitude and trend direction with our results (Fig. 5b), probably due to the greater temperature dependence of snowline in this area.

Previous studies have shown inconsistent findings related to snow changes for the same latitude range where we detected declining SP $\left(30-37^{\circ} \mathrm{S}\right)$. Several studies have documented increasing snow in the region. For example, Masiokas et al. (2006) showed a positive trend (not significant) of annual maximum SWE at five ground stations between years 1951 and 2005. These results differ from our study in the same area, probably because (1) the limited in situ observations that they used may not have been representative of the region as a whole, (2) the longer time period covered (54 years) may have had a different trend than the 2000-2016 time period examined here (Venable et al., 2012), and (3) the maximum SWE may not have the same trends as SP in this region. Another study found increases in snow days but decreases in maximum snow cover extent based on SnowModel simulations (1979-2014) in the Andes Cordillera south of $23^{\circ} \mathrm{S}$ (Mernild et al., 2017). Their findings highlight how interpretation of snow trends may vary with the snow variable selected. Again, the time period of analysis was different from our study, and this would also contribute to differences in snow cover trends, as trends identified in a time series can vary both in magnitude and direction for different time intervals (Fassnacht and Hultstrand, 2015).

Many prior studies have found declines in snow that are consistent with our findings here. Prieto et al. (2001) docu- 
(a) Coef. of determination, $r^{2}$

(b) Relative importance (RI), \%

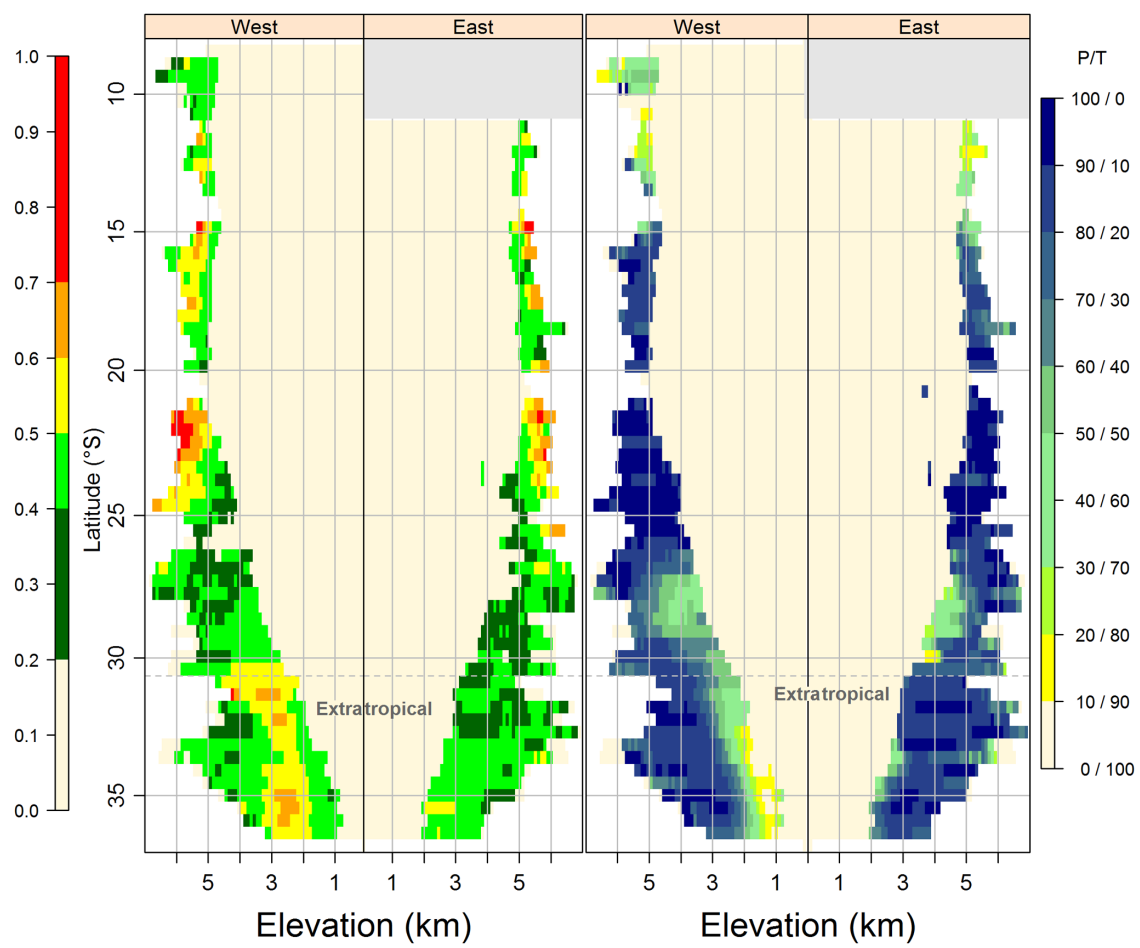

(c) $r^{2}$ vs. SP, midlat 2

(d) RI vs. SP, midlat 2
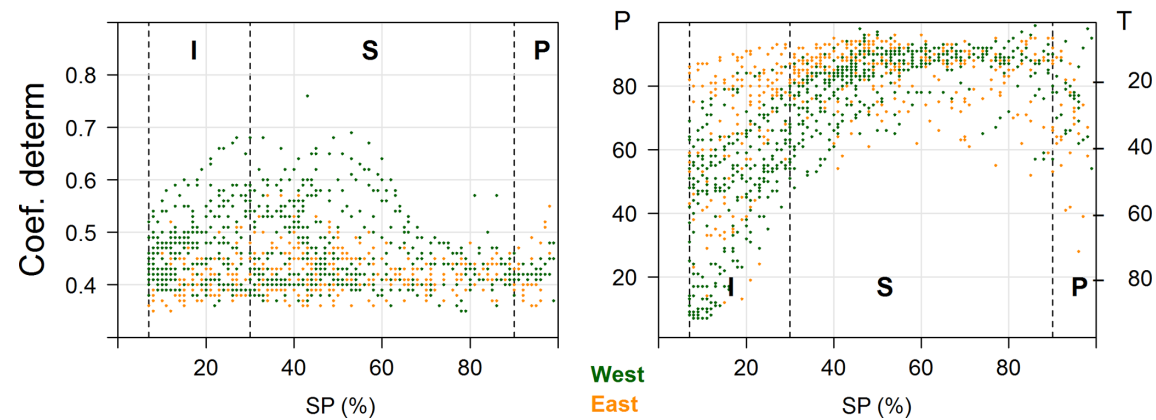

Figure 11. Latitude-elevation band analysis of the side of the continental divide (west-east) for (a) coefficient of determination $\left(r^{2}\right)$ for multiple linear regression using annual precipitation and mean air temperature to predict SP from 2000 to 2016 and (b) relative importance (RI) of $P / T$. Gray areas represent latitudes masked due to high frequency of cloud cover in snow-covered area analysis ( $>30 \%$ period). (c) $r^{2}$ vs. SP and (d) RI of $P / T$ in midlatitude 2 snow region for west (green) and east (orange) vs. SP values. Vertical dashed gray lines inside inset boxes represent thresholds for intermittent (I), seasonal (S), and persistent (P) snow zones.

mented a reduction in days with snow between years 1885 and 2000 in the Mendoza area of Argentina $\left(32.5^{\circ} \mathrm{S}\right.$, elevation $750 \mathrm{~m}$ ) based on newspaper weather reports, and this trend is consistent with our results in this area. Studies focused on glaciers found a general decrease in areas of snow and ice during time periods from 1983 to 2011 (Cortés et al., 2014), from 1955 to 1997 (Pellicciotti et al., 2013), and over the last 100 years (Masiokas et al., 2009). Glacierfocused studies do not capture the geographic range of our snow cover analysis, but these declines in glacier area are consistent with our findings of declining SP.

\subsection{Climatic causes of snow persistence trends}

Temperature increased throughout most of the Andes region, whereas SP only declined significantly in midlatitudes during the 2000-2016 time period. Many studies of snow pack change have focused on the importance of temperature to snow trends. In a warmer world, less winter precipitation falls as snow, and the melting of winter snow occurs earlier in spring (Barnett et al., 2005), explaining why snow cover is declining in most parts of the world when considered over large areas (Brown and Robinson, 2011). However, sitespecific snow trends vary (Vaughan et al., 2013; Fassnacht et 
al., 2016), likely due to the combined roles of temperature and precipitation affecting the snowpack (Adam et al., 2009; Stewart, 2009). Indeed, we found that trends in SP were detectable only where temperature was increasing while precipitation was decreasing (Fig. 6). In our study, precipitation emerged as the most important variable affecting SP across the midlatitude Andes, but temperature also affected SP in warmer areas such as the tropical latitudes and lower elevations of snowpack in midlatitudes. Climate modeling studies suggest that the trend of increasing temperature and declining precipitation will continue in this area (Bradley, 2004; GCOS, 2003), which will in turn affect streamflow in the region, where many of the rivers have snowmelt-dominated runoff (Cortés et al., 2011).

Both $T$ and $P$ are modulated by ENSO in the region (Masiokas et al., 2006; Santos, 2006; Zamboni et al., 2011; Meza, 2013; Valdés-Pineda et al., 2015b). In the tropics, El Niño conditions relate to low precipitation and warmer air temperatures, whereas in higher latitudes El Niño relates to higher precipitation and warmer temperatures (Garreaud et al., 2009). Our results suggest that this ENSO influence on temperature and precipitation most affects snow patterns north of $30^{\circ} \mathrm{S}$. The trends of decreasing $P$ and increasing $T$ we found in these latitudes are generally consistent with previous studies (Vuille and Bradley, 2000; Bradley, 2004; Quintana, 2012; Salzmann et al., 2013; Kluver and Leathers, 2015). South of $35^{\circ} \mathrm{S}, \mathrm{SAM}$ is the climate index best correlated with SP. The influence of SAM on South American climate has been documented in other studies (Vera and Silvestri, 2009; Fogt et al., 2010), and it has been found to be an important control on radial tree growth (ring width) in the same latitude range where we identified its influence on snow (Villalba et al., 2012). These relations between SAM and both tree rings and snowpack may indicate that SAM is influencing tree growth through its effect on snowpack characteristics. More specifically, snowpack can influence growing season length and water availability during the growing season. Given the relatively dry summers of this region, increased snowpack would be expected to increase radial tree growth by providing a source of moisture during the growing season. We present the first study relating SAM to snow response in South America, and these relations suggest that tree rings could be a viable method to reconstruct snowpack in the southern Andes (Woodhouse, 2003). However, we note that the short duration of our study time period is insufficient for complete analyses of how snow patterns relate to ENSO and SAM. During the period of our study SAM was mainly positive (Fig. 7b), so a long-term study is required to determine whether different phases of SAM have different snow cover responses.

The influences of climatic indices on snow are not always consistent with their influences on precipitation and temperature because the timing of precipitation and temperature anomalies is particularly important for snow. We found that in intermittent snow zones, where snow is not consistently present throughout the year, the greatest decreases in SP were during austral winter. Here, a decline in winter precipitation leads to a decline in snow and an increase in the elevation of the snowline. Higher up in the seasonal snow zone, where snow is present every year, the negative trends in SP were strongest in spring. These trends are explained primarily by temperature increases that accelerate the spring loss of snow, but they are also affected by the amount of winter and spring precipitation adding to snow accumulation.

Results of this study are affected by the accuracy of the snow cover and climate data. For snow cover we used the 8-day product to minimize cloud impairment, but this limited temporal resolution to 8 days. Future testing could evaluate whether these trends are consistent using daily or fractional SCA products (Rittger et al., 2013). These finer temporal resolution products will likely need to incorporate additional cloud removal algorithms (Gafurov and Bárdossy, 2009; Gao et al., 2011; Hall et al., 2010) in many areas to make an analysis feasible. Future analyses could therefore also examine how cloud presence may affect the direction and magnitude of SP trends. During the development of this paper, we tested several different gridded climate data products: UDelv4, MERRA2, ERA-Interim (Berrisford et al., 2011), and Global Historical Climatology NetworkMonthly (GHCN-M) (Lawrimore et al., 2011). Generally these products produced similar conclusions about how temperature and precipitation affect SP; however, there were notable differences in both the patterns and magnitudes of precipitation and temperature in these products. For example, there were no significant trends in precipitation north of $20^{\circ} \mathrm{S}$ in UDelv4, whereas some trends were present in MERRA2 (Fig. 6). UDelv4 showed some decreasing temperature trends from 15 to $29^{\circ} \mathrm{S}$, whereas MERRA2 had only increasing temperature trends in this area (Fig. 6). These examples highlight the importance of improving the quality of gridded climate products in the Andes.

\section{Conclusions}

This work quantifies trends in snow persistence across a large range of latitude $\left(9-36^{\circ} \mathrm{S}\right)$ and elevation $(0-6961 \mathrm{~m})$ on both sides of the Andes from 2000 to 2016. North of $29^{\circ}$ S (tropical latitudes and desert Andes), minimal changes in SP were detected because the areas with snow are small, and there were limited changes in precipitation from 2000 to 2016. South of $29^{\circ} \mathrm{S}$, significant loss of SP was observed in association with both increased temperature and decreased precipitation. Sixty-two percent of the area with significant SP loss was on the east side of the Andes. The absolute magnitude of these losses was greatest in areas with seasonal winter snow, whereas the greatest relative loss of snow persistence was in areas with intermittent winter snow, where the snowline increased in elevation. The relative importance of precipitation and temperature to SP varied with latitude and 
elevation. In most of the study region, precipitation had the greatest relative importance for SP, but temperature increased in importance in tropical latitudes and at lower elevations of midlatitudes. SP was highly correlated with temperature, precipitation, and climate indices across the region, with ENSO indices better predicting SP north of $31^{\circ} \mathrm{S}$ and the SAM better predicting SP south of $31^{\circ} \mathrm{S}$. The time period analyzed in this study is too short to document long-term snow changes, but they highlight the latitude and elevation variability in snow trends and the combined importance of precipitation and temperature in snow persistence. Continued monitoring of the spatial patterns of snow trends will help identify areas that are highly sensitive to climate change and aid in future water supply planning.

Data availability. Trend, correlation, and regression rasters for snow persistence, temperature, and precipitation are available by contacting the corresponding author.

Supplement. The supplement related to this article is available online at: https://doi.org/10.5194/tc-12-1027-2018-supplement.

Competing interests. The authors declare that they have no conflict of interest.

Acknowledgements. Saavedra's research has been supported by the Chilean government through the Fulbright-CONICYT scholarship program with additional support from NSF EAR-1446870 and CONICYT-FONDECYT Posdoctorado 3170651.

Edited by: Peter Morse

Reviewed by: three anonymous referees

\section{References}

Adam, J. C., Hamlet, A. F., and Lettenmaier, D. P.: Implications of global climate change for snowmelt hydrology in the twenty-first century, Hydrol. Process., 23, 962-972, https://doi.org/10.1002/hyp.7201, 2009.

Aravena, J.-C. and Luckman, B. H.: Spatio-temporal rainfall patterns in Southern South America, Int. J. Climatol., 29, 21062120, https://doi.org/10.1002/joc.1761, 2009.

Arsenault, K. R., Houser, P. R., and De Lannoy, G. J. M.: Evaluation of the MODIS snow cover fraction product, Hydrol. Process., 28, 980-998, https://doi.org/10.1002/hyp.9636, 2014.

Ayala, A., McPhee, J., and Vargas, X.: Altitudinal gradients, midwinter melt, and wind effects on snow accumulation in semiarid midlatitude Andes under La Niña conditions, Water Resour. Res., 50, 3589-3594, https://doi.org/10.1002/2013wr014960, 2014.

Barnett, T. P., Adam, J. C., and Lettenmaier, D. P.: Potential impacts of a warming climate on water avail- ability in snow-dominated regions, Nature, 438, 303-309, https://doi.org/10.1038/nature04141, 2005.

Barry, R. G.: Mountain Weather and Climate, 3rd Edn., University of Colorado, Boulder, USA, 2008.

Barry, R. G. and Seimon, A.: Research for Mountain Area Development: Climatic Fluctuations in the Mountains of the Americas and Their Significance, Ambio, 29, 364-370, https://doi.org/10.1579/0044-7447-29.7.364, 2000.

Berrisford, P., Dee, D. P., Poli, P., Brugge, R., Fielding, K., Fuentes, M., Kållberg, P. W., Kobayashi, S., Uppala, S., and Simmons, A.: The ERA-Interim archive Version 2.0, ERA Report Series, ECMWF, Shinfield Park, Reading, 23 pp., 2011.

Bradley, R. S.: Projected temperature changes along the American cordillera and the planned GCOS network, Geophys. Res. Lett., 31, L16210, https://doi.org/10.1029/2004g1020229, 2004.

Bradley, R. S., Vuille, M., Diaz, H. F., and Vergara, W.: Threats to Water Supplies in the Tropical Andes, Science, 312, 1755-1756, 2006.

Brown, R. D. and Mote, P. W.: The Response of Northern Hemisphere Snow Cover to a Changing Climate, J. Climate, 22, 21242145, https://doi.org/10.1175/2008jcli2665.1, 2009.

Brown, R. D. and Robinson, D. A.: Northern Hemisphere spring snow cover variability and change over 1922-2010 including an assessment of uncertainty, The Cryosphere, 5, 219-229, https://doi.org/10.5194/tc-5-219-2011, 2011.

Carrasco, J., Osorio, R., and Casassa, G.: Secular trend of the equilibrium-line altitude on the western side of the southern Andes, derived from radiosonde and surface observations, J. Glaciol., 54, 538-550, https://doi.org/10.3189/002214308785837002, 2008.

Cornwell, E., Molotch, N. P., and McPhee, J.: Spatio-temporal variability of snow water equivalent in the extra-tropical Andes Cordillera from distributed energy balance modeling and remotely sensed snow cover, Hydrol. Earth Syst. Sci., 20, 411-430, https://doi.org/10.5194/hess-20-411-2016, 2016.

Cortés, G. and Margulis, S.: Impacts of El Niño and La Niña on interannual snow accumulation in the Andes: Results from a highresolution 31 year reanalysis, Geophys. Res. Lett., 44, 68596867, https://doi.org/10.1002/2017g1073826, 2017.

Cortés, G., Vargas, X., and McPhee, J.: Climatic sensitivity of streamflow timing in the extratropical western Andes Cordillera, J. Hydrol., 405, 93-109, https://doi.org/10.1016/j.jhydrol.2011.05.013, 2011.

Cortés, G., Girotto, M., and Margulis, S. A.: Analysis of sub-pixel snow and ice extent over the extratropical Andes using spectral unmixing of historical Landsat imagery, Remote Sens. Environ., 141, 64-78, https://doi.org/10.1016/j.rse.2013.10.023, 2014.

Cortés, G., Girotto, M., and Margulis, S.: Snow process estimation over the extratropical Andes using a data assimilation framework integrating MERRA data and Landsat imagery, Water Resour. Res., 52, 2582-2600, https://doi.org/10.1002/2015wr018376, 2016.

Dahe, Q., Shiyin, L., and Peiji, L.: Snow Cover Distribution, Variability, and Response to Climate Change in Western China, J. Climate, 19, 1820-1833, https://doi.org/10.1175/JCLI3694.1, 2006.

Dettinger, M. D., Battisti, D. S., Garreaud, R. D., McCabe Jr., G. J., and Bitz, C. M.: Chapter 1 - Interhemispheric Effects of Interannual and Decadal ENSO-Like Climate Variations on the Ameri- 
cas A2 - Markgraf, Vera, in: Interhemispheric Climate Linkages, Academic Press, San Diego, 1-16, 2001.

Falvey, M. and Garreaud, R. D.: Regional cooling in a warming world: Recent temperature trends in the southeast Pacific and along the west coast of subtropical South America (1979-2006), J. Geophys. Res., 114, D04102, https://doi.org/10.1029/2008jd010519, 2009.

Fassnacht, S. R., and Hultstrand, M.: Snowpack variability and trends at long-term stations in northern Colorado, USA, Proceedings of the International Association of Hydrological Sciences, 371, 131-136, https://doi.org/10.5194/piahs-371-1312015, 2015

Fassnacht, S. R., Cherry, M. L., Venable, N. B. H., and Saavedra, F.: Snow and albedo climate change impacts across the United States Northern Great Plains, The Cryosphere, 10, 329339, https://doi.org/10.5194/tc-10-329-2016, 2016.

Fogt, R. L., Bromwich, D. H., and Hines, K. M.: Understanding the SAM influence on the South Pacific ENSO teleconnection, Clim. Dynam., 36, 1555-1576, https://doi.org/10.1007/s00382010-0905-0, 2010.

Foster, J. L., Hall, D. K., Kelly, R. E. J., and Chiu, L.: Seasonal snow extent and snow mass in South America using SMMR and SSM/I passive microwave data (1979-2006), Remote Sens. Environ., 113, 291-305, https://doi.org/10.1016/j.rse.2008.09.010, 2009.

Gafurov, A. and Bárdossy, A.: Cloud removal methodology from MODIS snow cover product, Hydrol. Earth Syst. Sci., 13, 13611373, https://doi.org/10.5194/hess-13-1361-2009, 2009.

Gao, Y., Lu, N., and Yao, T.: Evaluation of a cloudgap-filled MODIS daily snow cover product over the Pacific Northwest USA, J. Hydrol., 404, 157-165, https://doi.org/10.1016/j.jhydrol.2011.04.026, 2011.

Garreaud, R., Vuille, M., and Clement, A. C.: The climate of the Altiplano: observed current conditions and mechanisms of past changes, Palaeogeogr. Palaeocl., 194, 5-22, https://doi.org/10.1016/s0031-0182(03)00269-4, 2003.

Garreaud, R. D.: The Andes climate and weather, Adv. Geosci., 22, 3-11, https://doi.org/10.5194/adgeo-22-3-2009, 2009.

Garreaud, R. D., Vuille, M., Compagnucci, R., and Marengo, J.: Present-day South American climate, Palaeogeogr. Palaeocl., 281, 180-195, https://doi.org/10.1016/j.palaeo.2007.10.032, 2009.

Gascoin, S., Kinnard, C., Ponce, R., Lhermitte, S., MacDonell, S., and Rabatel, A.: Glacier contribution to streamflow in two headwaters of the Huasco River, Dry Andes of Chile, The Cryosphere, 5, 1099-1113, https://doi.org/10.5194/tc-5-1099-2011, 2011.

GCOS: Report of the GCOS Regional Workshop for South America on Improving Observing System for Climate, GCOS-86, World Meteorological Organization, 149 pp., 2003.

Gillett, N. P., Kell, T. D., and Jones, P. D.: Regional climate impacts of the Southern Annular Mode, Geophys. Res. Lett., 33, L23704, https://doi.org/10.1029/2006g1027721, 2006.

Groemping, U. and Matthias, L.: Relative importance of regressors in linear models, $\mathrm{R}$ package version 2.2, https://doi.org/10.1139/gen-2016-0039, 2013.

Grömping, U.: Relative Importance for Linear Regression in R: The Package relaimpo, J. Stat. Softw., 17, 1-27, https://doi.org/10.18637/jss.v017.i01, 2006.
Hall, D. K., Salomonson, V. V., and Riggs, G. A.: MODIS/Terra Snow Cover 8-Day L3 Global $500 \mathrm{~m}$ Grid, Version 5. MOD10A2, National Snow and Ice Data Center Distributed Active Archive Center, Boulder, Colorado USA, NASA, https://doi.org/10.5067/C574UGKQQU1T (last access: 1 September 2017), 2006.

Hall, D. K., Riggs, G. A., Salomonson, V. V., DiGirolamo, N. E., and Bayr, K. J.: MODIS snow-cover products, Remote Sens. Environ., 83, 181-194, https://doi.org/10.1016/S00344257(02)00095-0, 2002.

Hall, D. K., Riggs, G. A., Foster, J. L., and Kumar, S. V.: Development and evaluation of a cloud-gap-filled MODIS daily snow-cover product, Remote Sens. Environ., 114, 496-503, https://doi.org/10.1016/j.rse.2009.10.007, 2010.

Hall, D. K., Foster, J. L., DiGirolamo, N. E., and Riggs, G. A.: Snow cover, snowmelt timing and stream power in the Wind River Range, Wyoming, Geomorphology, 137, 87-93, https://doi.org/10.1016/j.geomorph.2010.11.011, 2012.

Hobbs, J. E., Lindesay, J., and Bridgeman, H. A.: Climates of the Southern Continents. Present, Past and Future, John Wiley and Sons, Chichester, UK, 1999.

Kennedy, M. and Kopp, S.: Understanding Map Projections, Environmental Systems Research Institute, Inc (ESRI), Redland, USA, 1994.

Khaled, H. H. and Ramachandra, A. R.: A modified Mann-Kendall trend test for autocorrelated data, J. Hydrol., 204, 182-196, https://doi.org/10.1016/S0022-1694(97)00125-X, 1998.

Kluver, D. and Leathers, D.: Regionalization of snowfall frequency and trends over the contiguous United States, Int. J. Climatol., 35, 4348-4358, https://doi.org/10.1002/joc.4292, 2015.

Knowles, N. and Cayan, D. R.: Elevational Dependence of Projected Hydrologic Changes in the San Francisco Estuary and Watershed, Climatic Change, 62, 319-336, https://doi.org/10.1023/B:CLIM.0000013696.14308.b9, 2004.

Lawrimore, J. H., Menne, M. J., Gleason, B. E., Williams, C. N., Wuertz, D. B., Vose, R. S., and Rennie, J.: An overview of the Global Historical Climatology Network monthly mean temperature data set, version 3, J. Geophys. Res., 116, D19121, https://doi.org/10.1029/2011JD016187, 2011.

Legates, D. R. and Willmott, C. J.: Mean seasonal and spatial variability in global surface air temperature, Theor. Appl. Climatol., 41, 11-21, https://doi.org/10.1007/BF00866198, 1990.

Liu, X., Cheng, Z., Yan, L., and Yin, Z.-Y.: Elevation dependency of recent and future minimum surface air temperature trends in the Tibetan Plateau and its surroundings, Global Planet. Change, 68, 164-174, https://doi.org/10.1016/j.gloplacha.2009.03.017, 2009.

Llamedo, P., Hierro, R., de la Torre, A., and Alexander, P.: ENSOrelated moisture and temperature anomalies over South America derived from GPS radio occultation profiles, Int. J. Climatol., 37, 268-275, https://doi.org/10.1002/joc.4702, 2016.

López-Moreno, J. I., Goyette, S., and Beniston, M.: Impact of climate change on snowpack in the Pyrenees: Horizontal spatial variability and vertical gradients, J. Hydrol., 374, 384-396, https://doi.org/10.1016/j.jhydrol.2009.06.049, 2009.

Marshall, G.: Trends in the Southern Annular Mode from Observations and Reanalyses, J. Climate, 16, 4134-4143, https://doi.org/10.1175/15200442(2003)016<4134:TITSAM>2.0.CO;2, 2003. 
Masiokas, M., Villalba, R., Luckman, B., Le Quesne, C., and Aravena, J. C.: Snowpack variations in the Central Andes of Argentina and Chile, 1951-2005: Large-scale atmospheric influences and implications for water resources in the region, J. Climate, 19, 6334-6352, https://doi.org/10.1175/JCLI3969.1, 2006.

Masiokas, M. H., Rivera, A., Espizua, L. E., Villalba, R., Delgado, S., and Aravena, J. C.: Glacier fluctuations in extratropical South America during the past 1000years, Palaeogeogr. Palaeocl., 281, 242-268, https://doi.org/10.1016/j.palaeo.2009.08.006, 2009.

Masiokas, M. H., Villalba, R., Luckman, B. H., and Mauget, S.: Intra- to Multidecadal Variations of Snowpack and Streamflow Records in the Andes of Chile and Argentina between $30^{\circ}$ and $37^{\circ} \mathrm{S}$, J. Hydrometeorol., 11, 822-831, https://doi.org/10.1175/2010jhm1191.1, 2010.

Masiokas, M. H., Villalba, R., Christie, D. A., Betman, E., Luckman, B. H., Le Quesne, C., Prieto, M. R., and Mauget, S.: Snowpack variations since $\mathrm{AD} 1150$ in the Andes of Chile and Argentina $\left(30^{\circ}-37^{\circ} \mathrm{S}\right)$ inferred from rainfall, tree-ring and documentary records, J. Geophys. Res., 117, D05112, https://doi.org/10.1029/2011jd016748, 2012.

Matsuura, K. and Willmott, C.: Terrestrial Air Temperature: 19002014 Gridded Monthly Time Series (Version 4.01), available at: http://climate.geog.udel.edu/ climate/html_pages/download. html (last access: January 2017), 2015.

McLeod, A. I.: Kendall-package: Kendall correlation and trend tests, available at: http://www.stats.uwo.ca/faculty/aim (last access: January 2017), 2011.

Mernild, S. H., Liston, G. E., Hiemstra, C. A., Malmros, J. K., Yde, J. C., and McPhee, J.: The Andes Cordillera. Part I: snow distribution, properties, and trends (1979-2014), Int. J. Climatol., 37, 1680-1698, https://doi.org/10.1002/joc.4804, 2017.

Meza, F. J.: Recent trends and ENSO influence on droughts in Northern Chile: An application of the Standardized Precipitation Evapotranspiration Index, Weather and Climate Extremes, 1, 5158, https://doi.org/10.1016/j.wace.2013.07.002, 2013.

Molod, A., Takacs, L., Suarez, M., and Bacmeister, J.: Development of the GEOS-5 atmospheric general circulation model: evolution from MERRA to MERRA2, Geosci. Model Dev., 8, 1339-1356, https://doi.org/10.5194/gmd-8-1339-2015, 2015.

Moore, C., Kampf, S., Stone, B., and Richer, E.: A GISbased method for defining snow zones: Aplication to the Western United States, Geocarto Int., 3, 62-81, https://doi.org/10.1080/10106049.2014.885089, 2015.

Peduzzi, P., Herold, C., and Silverio, W.: Assessing high altitude glacier thickness, volume and area changes using field, GIS and remote sensing techniques: the case of Nevado Coropuna (Peru), The Cryosphere, 4, 313-323, https://doi.org/10.5194/tc-4-3132010, 2010.

Pellicciotti, F., Burlando, P., and Van Vliet, K.: Recent trends in precipitation and streamflow in the Aconcagua River Basin, central Chile, in: Glacier Mass Balance Changes and Meltwater Discharge, IAHS Publ. 318, 17-38, 2007.

Pellicciotti, F., Ragettli, S., Carenzo, M., and McPhee, J.: Changes of glaciers in the Andes of Chile and priorities for future work, Sci. Total Environ., 493, 1197-1210, https://doi.org/10.1016/j.scitotenv.2013.10.055, 2013.

Pepin, N., Bradley, R. S., Diaz, H., Baraer, M., Caceres, E., Forsythe, N., Fowler, H., Greenwood, G., Hashmi, M., Liu, X., Miller, J. R., Ning, L., Ohmura, A., Palazzi, E., Rangwala,
I., Schoner, W., Severskiy, I., Shahgedonova, M., Wang, M., Williamsn, S., and Yang, D.: Elevation-dependent warming in mountain regions of the world, Nat. Clim. Change, 5, 424-430, https://doi.org/10.1038/nclimate2563, 2015.

Prieto, R., Herrera, R., and Dousel, P.: Interannual oscillations and trend of snow occurrence in the Andes region since 1885, Australian Meteorogical Magazine, 50, 164-168, 2001.

Quintana, J. M.: Changes in the rainfall regime along the extratropical west coast of South America (Chile): $30-43^{\circ} \mathrm{C}$, Atmosfera, 25, 1-22, 2012.

Rabatel, A., Francou, B., Soruco, A., Gomez, J., Cáceres, B., Ceballos, J. L., Basantes, R., Vuille, M., Sicart, J.-E., Huggel, C., Scheel, M., Lejeune, Y., Arnaud, Y., Collet, M., Condom, T., Consoli, G., Favier, V., Jomelli, V., Galarraga, R., Ginot, P., Maisincho, L., Mendoza, J., Ménégoz, M., Ramirez, E., Ribstein, P., Suarez, W., Villacis, M., and Wagnon, P.: Current state of glaciers in the tropical Andes: a multi-century perspective on glacier evolution and climate change, The Cryosphere, 7, 81102, https://doi.org/10.5194/tc-7-81-2013, 2013.

RCoreTeam: R: A language and environment for statistical computing, edited by: Computing, R. F. f. S., Vienna, Austria, 2013.

Riggs, G. A., Hall, D. K., and Salomonson, V. V.: MODIS snow products user guide to Collection 5, available at: https:// modis-snow-ice.gsfc.nasa.gov/uploads/siug_c5.pdf (last access: 1 September 2017), 2006.

Rittger, K., Painter, T. H., and Dozier, J.: Assessment of methods for mapping snow cover from MODIS, Adv. Water Resour., 51, 367380, https://doi.org/10.1016/j.advwatres.2012.03.002, 2013.

Rutllant, J. A. and Fuenzalida, H.: Synoptic Aspects of the Central Chile Rainfall Variability Associated with the Southern Oscillation, Int. J. Climatol., 11, 63-76, https://doi.org/10.1002/joc.3370110105, 1991.

Saavedra, F. A.: Spatial and Temporal Variability of Snow Cover in the Andes Mountains and Its influence on Streamflow in Snow Dominant Rivers, PhD thesis, Geoscience, Colorado State University, Fort Collins, 119 pp., 2016.

Saavedra, F. A., Kampf, S. K., Fassnacht, S. R., and Sibold, J. S.: A Snow Climatology of the Andes Mountains from MODIS Snow Cover Data, Int. J. Climatol., 37, 1526-1539, https://doi.org/10.1002/joc.4795, 2017.

Salzmann, N., Huggel, C., Rohrer, M., Silverio, W., Mark, B. G., Burns, P., and Portocarrero, C.: Glacier changes and climate trends derived from multiple sources in the data scarce Cordillera Vilcanota region, southern Peruvian Andes, The Cryosphere, 7, 103-118, https://doi.org/10.5194/tc-7-103-2013, 2013.

Santos, J. L.: The Impact of El Niño - Southern Oscillation Events on South America, Adv. Geosci., 6, 221-225, https://doi.org/10.5194/adgeo-6-221-2006, 2006.

Sen, P. K.: Estimates of the Regression Coefficient Based on Kendall's Tau, J. Am. Stat. Assoc., 63, 1379-1389, https://doi.org/10.1080/01621459.1968.10480934, 1968.

Stewart, I. T.: Changes in snowpack and snowmelt runoff for key mountain regions, Hydrol. Process., 23, 78-94, https://doi.org/10.1002/hyp.7128, 2009.

Theil, H.: A rank-invariant method of linear and polynomial regression analysis, Mathematic, 53, 386-392, 1950.

Valdés-Pineda, R., Pizarro, R., Valdés, J. B., Carrasco, J. F., GarcíaChevesich, P., and Olivares, C.: Spatio-temporal trends of precipitation, its aggressiveness and concentration, along the Pacific 
coast of South America (36-49 ${ }^{\circ}$ S), Hydrolog. Sci. J., 61, 21102132, https://doi.org/10.1080/02626667.2015.1085989, 2015a.

Valdés-Pineda, R., Valdés, J. B., Diaz, H. F., and Pizarro-Tapia, R.: Analysis of spatio-temporal changes in annual and seasonal precipitation variability in South America-Chile and related oceanatmosphere circulation patterns, Int. J. Climatol., 36, 2979-3001, https://doi.org/10.1002/joc.4532, 2015 b.

Vaughan, D. G., Comiso, J. C., Allison, I., Carrasco, J., Kaser, G., Kwok, R., Mote, P., Murray, T., Paul, F., Ren, J., Rignot, E., Solomina, O., Steffen, K., and Zhang, T.: Observations: Cryosphere, in: Climate Change 2013: The Physical Science Basis, Contribution of Working Group I to the Fifth Assessment Report of the Intergovernmental Panel on Climate Change, Cambridge University Press, New York, USA, 2013.

Venable, N. B. H., Fassnacht, S. R., Adyabadam, G., Tumenjargal, S., Fernandez-Gimenez, M., and Batbuyan, B.: Does the length of station record influence the warming trend that is perceived by Mongolian herders near the Khangai mountains?, Pirineos. Revista de Ecologia de Montana, 167, 71-88, https://doi.org/10.3989/Pirineos.2011.166004, 2012.

Vera, C. and Silvestri, G.: Precipitation interannual variability in South America from the WCRP-CMIP3 multi-model dataset, Clim. Dynam., 32, 1003-1014, https://doi.org/10.1007/s00382009-0534-7, 2009.

Villalba, R., Lara, A., Masiokas, M. H., Urrutia, R., Luckman, B. H., Marshall, G. J., Mundo, I. A., Christie, D. A., Cook, E. R., Neukom, R., Allen, K., Fenwick, P., Boninsegna, J. A., Srur, A. M., Morales, M. S., Araneo, D., Palmer, J. G., Cuq, E., Aravena, J. C., Holz, A., and LeQuesne, C.: Unusual Southern Hemisphere tree growth patterns induced by changes in the Southern Annular Mode, Nat. Geosci., 5, 793798, https://doi.org/10.1038/ngeo1613, 2012.
Vuille, M. and Ammann, C.: Regional Snowfall Patterns in the High, Arid Andes, Climatic Change, 36, 413-423, https://doi.org/10.1023/A:1005330802974, 1997.

Vuille, M. and Bradley, R. S.: Mean annual temperature trends and their vertical structure in the tropical Andes, Geophys. Res. Lett., 27, 3885-3888, https://doi.org/10.1029/2000g1011871, 2000.

Williams, R. and Ferringo, J.: Satellite Image Atlas of Glaciers of the World, South America, USGS, Washington, USA, 1998.

Willmott, C. J. and Matsuura, K.: Advantages of the mean absolute error (MAE) over the root mean square error (RMSE) in assessing average model performance, Clim. Res., 30, 79-82, https://doi.org/10.3354/cr030079, 2005.

Wolter, K. and Timlin, M. S.: Measuring the strength of ENSO events: How does 1997/98 rank?, Weather, 53, 315-324, https://doi.org/10.1002/j.1477-8696.1998.tb06408.x, 1998.

Woodhouse, C. A.: A 431-Yr Reconstruction of Western Colorado Snowpack from Tree Rings, J. Climate, 16, 1551-1561, https://doi.org/10.1175/1520-0442-16.10.1551, 2003.

Yi, Y., Kimball, J. S., Jones, L. A., Reichle, R. H., and McDonald, K. C.: Evaluation of MERRA Land Surface Estimates in Preparation for the Soil Moisture Active Passive Mission, J. Climate, 24, 3797-3816, https://doi.org/10.1175/2011jcli4034.1, 2011.

Zamboni, L., Kucharski, F., and Mechoso, C. R.: Seasonal variations of the links between the interannual variability of South America and the South Pacific, Clim. Dynam., 38, 2115-2129, https://doi.org/10.1007/s00382-011-1116-z, 2011.

Zhang, K., Kimball, J. S., and Running, S. W.: A review of remote sensing based actual evapotranspiration estimation, WIREs Water, 3, 834-853, https://doi.org/10.1002/wat2.1168, 2016. 